\title{
Differential actions of orexin receptors in brainstem cholinergic and monoaminergic neurons revealed by receptor knockouts: implications for orexinergic signaling in arousal and narcolepsy
}

\author{
Kristi A. Kohlmeier ${ }^{1}$, Christopher J. Tyler ${ }^{2}$, Mike Kalogiannis ${ }^{2}$, Masaru Ishibashi ${ }^{2}$, \\ Morten P. Kristensen ${ }^{1}$, Iryna Gumenchuk ${ }^{2}$, Richard M. Chemelli ${ }^{3}$, Yaz Y. Kisanuki ${ }^{3+}$, \\ Masashi Yanagisawa $^{3}$ and Christopher S. Leonard ${ }^{2}$.
}

\author{
${ }^{1}$ Department of Drug Design and Pharmacology, Faculty of Health and Medical Sciences, University of Copenhagen, Copenhagen, Denmark \\ 2 Department of Physiology, New York Medical College, Valhalla, NY, USA \\ ${ }^{3}$ Howard Hughes Medical Institute, University of Texas Southwestern Medical Center, Dallas, TX, USA
}

\section{Edited by:}

Christopher J. Winrow, Merck \&

Co., Inc., USA

\section{Reviewed by:}

Gregg Stanwood, Vanderbilt

University, USA

Jafri M. Abdullah, Universiti Sains

Malaysia, Malaysia

Christie D. Fowler, The Scripps

Research Institute, USA

*Correspondence:

Christopher S. Leonard, Department

of Physiology, New York Medical

College, 15 Dana Road, Valhalla,

NY 10595, USA

e-mail: chris_leonard@nymc.ed

${ }^{\dagger}$ Present address:

Yaz Y. Kisanuki, Department of Neurology, Division of

Neurogenetics, The Ohio State

University Wexner Medical Center,

Columbus, $\mathrm{OH}, \mathrm{USA}$
Orexin neuropeptides influence multiple homeostatic functions and play an essential role in the expression of normal sleep-wake behavior. While their two known receptors $\left(\mathrm{OX}_{1}\right.$ and $\left.\mathrm{OX}_{2}\right)$ are targets for novel pharmacotherapeutics, the actions mediated by each receptor remain largely unexplored. Using brain slices from mice constitutively lacking either receptor, we used whole-cell and $\mathrm{Ca}^{2+}$ imaging methods to delineate the cellular actions of each receptor within cholinergic [laterodorsal tegmental nucleus (LDT)] and monoaminergic [dorsal raphe (DR) and locus coeruleus (LC)] brainstem nuclei-where orexins promote arousal and suppress REM sleep. In slices from $\mathrm{OX}_{2}^{-/-}$mice, orexin-A $(300 \mathrm{nM})$ elicited wild-type responses in LDT, DR, and LC neurons consisting of a depolarizing current and augmented voltage-dependent $\mathrm{Ca}^{2+}$ transients. In slices from $\mathrm{OX}_{1}^{-1-}$ mice, the depolarizing current was absent in LDT and LC neurons and was attenuated in DR neurons, although $\mathrm{Ca}^{2+}$-transients were still augmented. Since orexin-A produced neither of these actions in slices lacking both receptors, our findings suggest that orexin-mediated depolarization is mediated by both receptors in DR, but is exclusively mediated by $\mathrm{OX}_{1}$ in LDT and LC neurons, even though $\mathrm{OX}_{2}$ is present and $\mathrm{OX}_{2}$ mRNA appears elevated in brainstems from $\mathrm{OX}_{1}^{-/-}$mice. Considering published behavioral data, these findings support a model in which orexin-mediated excitation of mesopontine cholinergic and monoaminergic neurons contributes little to stabilizing spontaneous waking and sleep bouts, but functions in context-dependent arousal and helps restrict muscle atonia to REM sleep. The augmented $\mathrm{Ca}^{2+}$ transients produced by both receptors appeared mediated by influx via L-type $\mathrm{Ca}^{2+}$ channels, which is often linked to transcriptional signaling. This could provide an adaptive signal to compensate for receptor loss or prolonged antagonism and may contribute to the reduced severity of narcolepsy in single receptor knockout mice.

Keywords: laterodorsal tegmental nucleus, dorsal raphe nucleus, locus coeruleus, whole-cell patch-clamp recording, $\mathrm{Ca}^{2+}$ signaling

\section{INTRODUCTION}

Orexin-A and Orexin-B, also called hypocretin-1 and -2, are two hypothalamic neuropeptides (De Lecea et al., 1998; Sakurai et al., 1998) that influence feeding, metabolism, arousal, reward, and stress substrates in the CNS (for review, see Tsujino and Sakurai, 2009). The orexin system plays a particularly important role in the normal expression of waking and sleep since its disruption underlies the sleep disorder narcolepsy with cataplexy in humans (Peyron et al., 2000; Thannickal et al., 2000) and produces a narcolepsy phenotype with unstable behavioral states, sleep attacks and cataplexy-like motor arrests in animals (Chemelli et al., 1999; Lin et al., 1999; Hara et al., 2001; Willie et al., 2003; Beuckmann et al., 2004; Mochizuki et al., 2004; Kalogiannis et al., 2011).
Orexin actions are mediated by two G-protein coupled receptors (Sakurai et al., 1998), termed orexin-1 (OX 1 ) and orexin-2 $\left(\mathrm{OX}_{2}\right)$ receptors, which have partly overlapping and widespread expression patterns in the CNS (Trivedi et al., 1998; Hervieu et al., 2001; Marcus et al., 2001). These receptors are attractive targets for the development of a range of novel therapeutic agents with potential for treating sleep disorders, obesity, stressrelated disorders, and addiction. The first orexin-related drugs to appear will be the dual orexin receptor antagonists (DORAs) for the treatment of insomnia (Uslaner et al., 2013; Winrow and Renger, 2013), but there is significant interest in developing single orexin receptor-specific antagonists (SORAs). However, much remains unknown about the cellular actions of each receptor and 
the behavioral consequences of activation or inhibition of each receptor at their many targets.

In this study, we focus on mesopontine cholinergic [laterodorsal tegmental nucleus (LDT)] and monoaminergic [dorsal raphe (DR) and locus coeruleus (LC)] neurons, which participate in a spectrum of functions that include the control of arousal and sleep (Jones, 2005; Brown et al., 2012), the maintenance of motor activity and muscle tone during arousal (Jacobs and Fornal, 1993; Michelsen et al., 2007), the mediation of stress related actions and adaptation (Lowry et al., 2005; Valentino and Van Bockstaele, 2008) and the stimulation of motivated behavior via projections to midbrain dopamine systems (Maskos, 2008; Mena-Segovia et al., 2008). These structures, and especially the LC, receive substantial orexinergic innervation (Peyron et al., 1998; Chemelli et al., 1999; Nambu et al., 1999), and orexin terminals have been shown to synapse upon tyrosine hydroxylase immunoreactive neurons in LC (Horvath et al., 1999), cholinergic neurons in the LDT (Cid-Pellitero and Garzón, 2011) and DR neurons (Del CidPellitero and Garzón, 2011). Evidence from in-situ hybridization studies in rat (Marcus et al., 2001) indicate that moderate levels of $\mathrm{OX}_{1}$ mRNA are expressed in LDT and DR while especially high levels of $\mathrm{OX}_{1}$ mRNA are expressed in the LC. These studies also found moderate levels of $\mathrm{OX}_{2}$ mRNA levels in the DR with lower levels in the LDT and LC. Consistent with this innervation pattern and receptor distribution, exogenously applied orexins directly depolarize LDT (Burlet et al., 2002; Kohlmeier et al., 2008) and related PPT (Kim et al., 2009) neurons, along with DR (Brown et al., 2002; Liu et al., 2002; Kohlmeier et al., 2008) and LC neurons (Horvath et al., 1999; Ivanov and Aston-Jones, 2000; Li et al., 2002; Hoang et al., 2003; Murai and Akaike, 2005) partly, by activating a cation current. Orexin-A has also been shown previously to have a distinct modulatory role in the LDT and DR by augmenting the $\mathrm{Ca}^{2+}$ influx mediated by L-type $\mathrm{Ca}^{2+}$ channels (Kohlmeier et al., 2008). However, the roles played by each receptor in these actions are unknown.

Early studies of orexin receptors using heterologous expression found that both receptors stimulate $\mathrm{Ca}^{2+}$-release from intracellular stores (Sakurai et al., 1998; Smart et al., 1999) and activate phospholipase C (PLC) (Lund et al., 2000; Holmqvist et al., 2002), suggesting they are $G_{q}$ coupled receptors. More recent studies indicate these receptors can couple to multiple G-proteins and therefore may utilize more diverse signaling cascades, however, much less is known about the signaling targets of native orexin receptors (for review see Kukkonen and Leonard, 2013). Evidence from studies of brain slices or freshly dissociated neurons indicate that native orexin receptors mediate neuronal depolarization from resting membrane potential by activating three classes of effectors (for review see Leonard and Kukkonen, 2013): closure of $\mathrm{K}^{+}$channels (Ivanov and Aston-Jones, 2000; Hwang et al., 2001; Bayer et al., 2002; Grabauskas and Moises, 2003; Hoang et al., 2003, 2004; Ishibashi et al., 2005; Bisetti et al., 2006), forward activation of the electrogenic $\mathrm{Na}^{+} / \mathrm{Ca}^{2+}$ exchanger (Eriksson et al., 2001; Wu et al., 2002, 2004; Burdakov et al., 2003), activation of a cation current (Brown et al., 2002; Yang and Ferguson, 2002, 2003; Murai and Akaike, 2005; Kohlmeier et al., 2008) and can elevate intracellular $\left[\mathrm{Ca}^{2+}\right.$ ] (Van Den Pol et al., 1998; Van Den Pol, 1999; Uramura et al., 2001; Xu et al., 2002; Kohlmeier et al., 2004,
2008; Ishibashi et al., 2005). Only limited information is available about the particular receptors mediating these actions, especially since receptor overlap is common and subtype-specific antagonists are lacking. Conclusions about native receptor function has often relied upon the relative potencies of orexin-A and $-\mathrm{B}$, based on the high potency of orexin-A for both receptors and the $\sim 10$ fold lower potency of orexin-B for $\mathrm{OX}_{1}$ expressed in $\mathrm{CHO}$ cells (Sakurai et al., 1998). However, agonist-based receptor determinations have numerous potential confounds (see Leonard and Kukkonen, 2013) including differing stability of agonists, differing receptor levels and the possibility of biased agonism, as has been proposed for expressed orexin receptors (Putula et al., 2011).

To avoid these potential limitations, we sought to determine the actions of each receptor in LDT, DR, and LC neurons using a genetic dissection approach: We examined the actions by each receptor using whole-cell recording and $\mathrm{Ca}^{2+}$ imaging methods in brain slices from knockout mice constitutively lacking either receptor thereby allowing us to determine the functional capacity of each receptor in isolation. This revealed that $\mathrm{OX}_{1}$ and $\mathrm{OX}_{2}$ have both convergent and unique functions in LDT, DR, and LC neurons. These findings have implications for understanding the cellular functions of orexin receptors, the behavioral consequences of orexin signaling at these loci and some consequences for using receptor specific antagonists as therapeutics.

\section{MATERIALS AND METHODS}

All procedures complied with National Institutes of Health (US) and institutional guidelines (New York Medical College) for ethical use of animals and were approved by the New York Medical College Institutional Animal Care and Use Committee (IACUC).

\section{ANIMALS AND GENOTYPING}

Brain slices for whole cell recordings were prepared from 14 to 32 day old C57BL6, background control (orexin receptor wild-type; OxrWT), $\mathrm{OX}_{2}^{-/-}, \mathrm{OX}_{1}^{-/-}$, and $\mathrm{OX}_{1}^{-/-} / \mathrm{OX}_{2}^{-/-}$double knockout $(\mathrm{DKO})$ mice. In those cases where calcium imaging was being performed with the cell permeant fura-2AM, mice aged 9-15 days old were utilized. Both male and female mice were used in this study and receptor knockout mice were the offspring of breeders that were both homozygous for the null alleles on mixed C57BL6 and $129 \mathrm{SvEv}$ genetic backgrounds. The OxrWT mice were bred from the wild-type progeny of the $\mathrm{OX}_{2}^{+/-}$parents used to make the $\mathrm{OX}_{2}^{-/-}$mice. The OxrWT, $\mathrm{OX}_{2}^{-/-}, \mathrm{OX}_{1}^{-/-}$, and DKO mice have been described previously (Willie et al., 2003; Kalogiannis et al., 2011; Mieda et al., 2011).

To confirm genotypes, tail biopsies were obtained during slice preparation and subsequently analyzed by PCR. One set of primers were used to determine if the mouse was either a wild-type or knockout for each orexin receptor. The three primers for $\mathrm{OX}_{1}$ consisted of a common primer (5'-CTCTTTC TCCACAGAGCCCAGGACTC-3'), a knockout primer (5'-TGA GCGAGTAACAACCCGTCGGATTC- $3^{\prime}$ ) and a wild-type primer (5'gCAAGAATGGGTATGAAGGGAAGGGC-3'). The expected product sizes were $\sim 320$ base pairs for the wild-type allele and $\sim 500$ base pairs for the knockout allele. The three primers for $\mathrm{OX}_{2}$ consisted of a common primer $\left(5^{\prime}\right.$-CTGGTGCAAATCCCC TGCAAA- $\left.3^{\prime}\right)$, a knockout primer (5'-GGTTTTCCCAGTCAC 
GACGTTGTA- $3^{\prime}$ ) and a wild-type primer (5'-AATCCTTCTAGA GATCCCTCCTAG- $3^{\prime}$ ). The expected product sizes were $\sim 620$ base pairs for wild-type allele and $\sim 300$ base pairs for the knockout allele. These two sets of primers for different orexin receptors were processed separately. PCR amplification consisted of denaturation at $95^{\circ} \mathrm{C}$ for $8 \mathrm{~min}$ followed by 35 cycles of $94^{\circ} \mathrm{C}(30 \mathrm{~s}), 62^{\circ} \mathrm{C}$ (30 s) and $72^{\circ} \mathrm{C}(1 \mathrm{~min})$, followed by one cycle at $72^{\circ} \mathrm{C}$ for $10 \mathrm{~min}$. The result of each PCR reaction was then separated using a $2 \%$ agarose gel, and the PCR product was visualized with ethidium bromide.

\section{BRAIN SLICES AND ELECTROPHYSIOLOGY}

Brain slices $(250 \mu \mathrm{m})$ were prepared using a Leica vibratome (VT1000S) in ice-cold artificial cerebrospinal fluid (ACSF) which contained (in mM): $121 \mathrm{NaCl}, 5 \mathrm{KCl}, 1.2 \mathrm{NaH}_{2} \mathrm{PO}_{4}, 2.7 \mathrm{CaCl}_{2}$, $1.2 \mathrm{MgSO}_{4}, 26 \mathrm{NaHCO}_{3}, 20$ dextrose, 4.2 lactic acid and was oxygenated by bubbling with carbogen $\left(95 \% \mathrm{O}_{2}\right.$ and $\left.5 \% \mathrm{CO}_{2}\right)$. Slices containing the LDT, DR, or LC were incubated at $35^{\circ} \mathrm{C}$ for $15 \mathrm{~min}$ in oxygenated ACSF, and were then stored at room temperature in continuously oxygenated ACSF, until they were utilized for recordings.

For recording, slices were placed in a submersion chamber on a fixed-stage microscope (Olympus BX50WI) and superfused $(1-2 \mathrm{ml} / \mathrm{min})$ with $\operatorname{ACSF}\left(23 \pm 2^{\circ} \mathrm{C}\right)$. Regions for recording were chosen from within the boundaries of the LDT, DR, or LC nuclei determined using a $4 \mathrm{X}$ objective and brightfield illumination. Neurons were then visualized with a video camera and DIC optics using a 40X water immersion objective (Olympus; NA 0.8 ). Large to medium sized multipolar neurons were selected for gigaseal recording in voltage clamp or current clamp mode using an Axoclamp 2A or Axopatch 2A or 2B amplifier (Axon Instruments). Borosilicate patch pipettes ( $2-5 \mathrm{MOhms}$; cat number 8050, AM systems) containing a solution of (in mM) 144 K-Gluconate, 0.2 EGTA, $3 \mathrm{MgCl}_{2}, 10$ HEPES, $0.3 \mathrm{NaGTP}, 4$ $\mathrm{Na}_{2}$ ATP. Biocytin (0.1\%) with the Na-GTP added to the pipette solution just before use.

\section{DRUGS AND EXPERIMENTAL SOLUTIONS}

Normal ACSF contained (in $\mathrm{mM}$ ) $124 \mathrm{NaCl}, 5 \mathrm{KCl}, 1.2$ $\mathrm{NaH}_{2} \mathrm{PO}_{4}, 2.7 \mathrm{CaCl}_{2}, 1.2 \mathrm{MgSO}_{4}, 26 \mathrm{NaHCO}_{3}$ and 10 dextrose (295-305 mOsm). To block voltage-gated sodium channels and fast synaptic potentials, the ACSF (DABST-containing) contained the ionotropic receptor antagonists $\underline{D} N Q X(15 \mu \mathrm{M}$, Sigma), $\underline{\mathrm{APV}}$

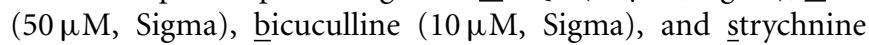
$(2.5 \mu \mathrm{M}$, Sigma) with TTX ( $500 \mathrm{nM}$, Alomone). To measure the average orexin-A mediated post-synaptic current and its I-V relation in LDT and DR neurons, $\mathrm{CsCl}(2$ or $3 \mathrm{mM})$ was added to the DABST to block $\mathrm{H}$-current and a low $\mathrm{Ca}^{2+}$ ACSF was used to inhibit voltage-gated $\mathrm{Ca}^{2+}$ currents. $\left[\mathrm{Ca}^{2+}\right]$ was buffered to $<20 \mu \mathrm{M}$ by the addition of $2.7 \mathrm{mM}$ EGTA (calculated with Patcher's Power Tools XOP for Igor Pro). Orexin-A (Sigma, USA; Phoenix Pharmaceuticals, USA; American Peptides, USA; Peptide international, USA) was dissolved in deionized water or physiological saline in $1 \mathrm{mM}$ aliquots and frozen $\left(-80^{\circ} \mathrm{C}\right)$. Aliquots were dissolved in ACSF to a final concentration of $300 \mathrm{nM}$ immediately before use. The L-type $\mathrm{Ca}^{2+}$ channel antagonist nifedipine and agonist, Bay-K-8644 (Bay-K; Sigma, USA) were dissolved in DMSO to a stock concentration of $10 \mathrm{mM}$ and delivered at the final concentration of $10 \mu \mathrm{M}$ in ACSF. Bisindolylmaleimide I, $\mathrm{HCl}$ (Calbiochem, EMD Biosciences) was dissolved in DMSO to a stock concentration of $5 \mathrm{mM}$. On the day of experiments it was diluted in TTX-ACSF to a final concentration of $1 \mu \mathrm{M}$ and applied for $5 \mathrm{~min}$ prior to application of orexin. Final dilutions of these drugs were made immediately before application and light exposure was minimized throughout preparation and application.

\section{$\mathrm{Ca}^{2+}$ IMAGING}

Fluorescence related to intracellular calcium concentration was measured from neurons in slices that had been either individually filled with bis-fura- 2 from patch pipettes or bulk-loaded with fura-2AM. The patch solution for $\mathrm{Ca}^{2+}$ imaging contained the potassium salt of bis-fura-2 (50 $\mu \mathrm{M}$, Molecular Probes) dissolved in a solution containing (in $\mathrm{mM}$ ) $144 \mathrm{~K}$-gluconate, 3 $\mathrm{MgCl}_{2}, 10$ HEPES, $0.3 \mathrm{NaGTP}$, and $4 \mathrm{Na}_{2}$ ATP. Biocytin (0.1\%) or biotinylated Alexa-594 (25 $\mu \mathrm{M}$; Invitrogen) was included in all experiments for cell identification following slice fixation.

For bulk loading neurons with fura-2, slices from young mice (P6-P17) were incubated in ACSF containing $15 \mu \mathrm{M}$ fura-2AM (Molecular Probes) prepared from a $3.3 \mathrm{mM}$ stock of fura-2AM in DMSO. Slices were incubated for $30 \mathrm{~min}$ at $36^{\circ} \mathrm{C}$ in a small volume equilibrated with Carbogen $\left(5 \% \mathrm{CO}_{2} / 95 \% \mathrm{O}_{2}\right)$. Slices were then transferred to the recording chamber and rinsed for at least $30 \mathrm{~min}$ to ensure de-esterification and temperature equilibration. After locating a recording region in the LDT, DR, or LC, individual cells were imaged with the $40 \times$ water immersion lens.

$\mathrm{Ca}^{2+}$ transients were monitored by measuring the emission at $515 \mathrm{~nm}$ resulting from excitation of fura-2 with $380 \mathrm{~nm}\left(\mathrm{~F}_{380}\right.$; 71000 Chroma fura-2 filter set) from a shuttered 75W Xenon light source. Optical recordings were made using a back illuminated, frame-transfer, cooled CCD camera system (EEV 57 chip, Micromax System, Roper Scientific) that was controlled with custom software (TI Workbench) running on a Mac OS computer. Images were either acquired discontinuously (every $1-4 \mathrm{~s}$ ) with the shutter closed between images (600 ms exposure) or continuously ( $\sim 50 \mathrm{~ms} /$ frame), with the shutter open for the entire epoch. Changes in intracellular calcium concentration were inferred from changes in delta $\mathrm{F} / \mathrm{F}(\mathrm{dF} / \mathrm{F})$ where $\mathrm{F}$ is the fluorescence at rest within a ROI following subtraction of background fluorescence. $\mathrm{dF}$ is the change in fluorescence following subtraction of the average $\mathrm{F}$ prior to stimulation. $\mathrm{dF} / \mathrm{F}$ was usually corrected for photobleaching. Since rises in $\left[\mathrm{Ca}^{2+}\right]$ produce a decrease in $\mathrm{F}_{380}$ with fura-2, all dF/F measures are inverted so positive-going traces indicate elevation of $\left[\mathrm{Ca}^{2+}\right]_{i}$.

\section{IMMUNOCYTOCHEMISTRY}

Recorded neurons were identified as cholinergic, serotonergic or noradrenergic by using conventional immunocytochemistry following slice fixation in $4 \%$ paraformaldehyde, cryoprotection and re-sectioning at $40 \mu \mathrm{m}$ on a freezing microtome. Filled neurons were visualized with avidin-Texas Red or Alexa-594 biocytin. Cholinergic neurons in the LDT selectively co-localize the enzyme neuronal nitric oxide synthase (nNOS; Vincent et al., 1983) and were identified by immunolabeling for nNOS (1:400 rabbit 
polyclonal, Sigma, Cat N7280). Serotonergic neurons in the DR were identified by immunolabeling for tryptophan hydroxylase (TpH; 1:400 sheep polyclonal, Abcam, 3907 and Covance, PSH327P). Catecholamine neurons in the LC were identified by immunolabeling for tyrosine hydroxylase $(\mathrm{TH} ; 1: 1000$, rabbit polyclonal, Abcam, Cat 112). For immunofluorescence, primary antibodies were visualized with FITC or Alexa 488-labeled secondary antibodies. Following washing and mounting, cleared sections were imaged using appropriate filter sets with a CCD camera (Coolsnap, Roper Scientific or QICam, QImaging) mounted on an epi-fluorescence microscope (BX60; Olympus). For immunohistochemistry primary antibodies were visualized with biotinylated secondary antibodies and the tissue was processed with a Vector ABC kit as per the manufacturer's instructions and reacted with Sigma's FastDAB kit for 5 min (Sigma-Aldrich, St. Louis, $\mathrm{MO}$ ). The precipitation reaction was stopped with three rises of PBS and the sections were mounted on slides and coverslipped.

\section{RNA ISOLATION FROM WHOLE BRAINSTEM}

To isolate RNA from whole brainstems, C57BL6, $\mathrm{OX}_{1}^{-/-}, \mathrm{OX}_{2}^{-/-}$, $\mathrm{DKO}$, and 129SvEv mice were anesthetized and decapitated as for brain slices. The brainstems were then rapidly dissected from the whole brain starting $\sim 5 \mathrm{~mm}$ anterior to the superior colliculus to the medulla, and the cerebellum was removed. The brainstems were then flash-frozen in liquid nitrogen. Total RNA was isolated from the frozen tissue using the RNeasy Lipid Tissue Mini kit (Qiagen). RNA quality and quantity was determined by the A260/A280 ratio from the spectrophotometer.

Standards were generated from cDNA isolated from the C57BL6 brainstem. The cDNA was loaded with primers of the gene of interest and amplified using a conventional PCR for 35 cycles. The product was then run on a gel to determine the specificity of the amplification. If there was a single band of the predicted size, the concentration of the PCR product was determined through spectrophotometry and serially diluted. This technique was utilized with all the primers to create scales unique for each gene of interest. These scales were used to correlate target mRNA fluorescence to sample starting concentration. Scales were created for $\mathrm{OX}_{1}$ and for each of the two splice variants of $\mathrm{OX}_{2}$ identified in mouse: $\mathrm{OX}_{2} \alpha$ and $\mathrm{OX}_{2} \beta$ (Chen and Randeva, 2004; Chen et al., 2006). $\mathrm{OX}_{1}$ mRNA scales ranged from $1.8 \times 10^{-2}$ to $1.8 \times 10^{-5} \mu \mathrm{g} / \mathrm{ml} . \mathrm{OX}_{2} \alpha \mathrm{mRNA}$ scales ranged from $7.7 \times 10^{-2}$ to $7.7 \times 10^{-5} \mu \mathrm{g} / \mathrm{ml} . \mathrm{OX}_{2} \beta \mathrm{mRNA}$ scale ranged from $9.0 \times 10^{-3}$ to $9.0 \times 10^{-6} \mu \mathrm{g} / \mathrm{ml}$.

\section{LIGHT CYCLER REAL TIME PCR}

A $20 \mu \mathrm{l}$ volume of the RNA solution, with $\sim 1 \mu \mathrm{g}$ of total RNA from each sample was reverse transcribed using random primers and the Improm II Reverse Transcription (RT) kit (Promega). The samples were incubated with random primers for $5 \mathrm{~min}$ at $70^{\circ} \mathrm{C}, 5 \mathrm{~min}$ at $4^{\circ} \mathrm{C}$ and $1 \mathrm{~h}$ at $37^{\circ} \mathrm{C}$ followed by $70^{\circ} \mathrm{C}$ for $15 \mathrm{~min}$. The RT product was then aliquoted and stored at $-20^{\circ} \mathrm{C}$. Two microliters of the RT product were loaded with SYBR green I reagent, $25 \mathrm{mM} \mathrm{MgCl}_{2}$ and primers to a final volume of $20 \mu \mathrm{l}$. Primers for $\mathrm{OX}_{1}, \mathrm{OX}_{2} \alpha$, and $\mathrm{OX}_{2} \beta$ were loaded at a constant concentration $(10 \mu \mathrm{M})$ for their respective runs (Invitrogen). The following sequences were used to amplify the genes of interest: $\mathrm{OX}_{1}$ forward: 5'-TGCCGCCAACCCTATC
ATCT-3' reverse: 5'-GTGACGGTGGTCAGCACGAC-3' (which corresponds to pubmed genbank NM_198959, 1364-1547); $\mathrm{OX}_{2} \alpha$ forward: 5'-GAGACAAGCTTGCAGCACTGAG-3' reverse: $5^{\prime}$ TGAGTCGGGTATCCTCATCATAG-3'; $\mathrm{OX}_{2} \beta$ forward: $5^{\prime}-\mathrm{GAG}$ ACAAGCTTGCAGCACTGAG-3' reverse: $5^{\prime}$-GGTCGGTCAATG TCCAATGTTC-3' (Chen and Randeva, 2004; Chen et al., 2006). Each sample was loaded in duplicate (Roche, Lightcycler RTPCR). Light cycler protocols for mRNA quantification consisted of denaturation at $95^{\circ} \mathrm{C}(485 \mathrm{~s})$, cycling 40 times at $94^{\circ} \mathrm{C}(5 \mathrm{~s})$, $64^{\circ} \mathrm{C}(10 \mathrm{~s})$, and $76^{\circ} \mathrm{C}(14 \mathrm{~s})$. The same amount of total RNA was loaded into each capillary tube for the lightcycler. The measured starting amount of target mRNA was then normalized by the amount of total RNA loaded. The mRNA/total RNA ratios were subsequently compared between samples obtained from C57BL6, $\mathrm{OX}_{1}^{-/-}, \mathrm{OX}_{2}^{-/-}, \mathrm{DKO}$, and $129 \mathrm{SvEv}$ mice. Lightcycler products were then visualized with ethidium bromide in $2 \%$ agarose gels to confirm the presence of the RT-PCR target.

\section{DATA ANALYSIS}

Data analysis and figure preparation was done using Igor Pro (Wavemetrics) software. Differences between means were determined by paired or unpaired Student's $t$-test or a One Way ANOVA using MS excel or DataDesk 6 software (Data Description, Inc). Non-parametric comparisons were conducted utilizing Chi-Square analysis using excel or DataDesk 6 or the Kolmogorov-Smirnov test using Igor Pro. Numerical results are reported as mean $\pm \mathrm{SEM}$.

\section{RESULTS \\ PRINCIPAL NEURONS IN THE LDT, DR, AND LC APPEAR NORMAL IN OREXIN RECEPTOR NULL MICE}

To determine if the absence of orexin receptors resulted in gross anomalies in the development of brainstem cholinergic and monoaminergic nuclei, we inspected immunohistochemically stained tissue sections through the LDT, DR, and LC. We examined $\mathrm{nNOS}, \mathrm{TpH}$, and $\mathrm{TH}$ staining in sections from C57BL6 mice $(n=2)$ and from mice lacking one or both receptors ( $n=2$ for each genotype). Figure 1 shows comparable tissue sections through the LDT, DR, and LC from a C57BL6 mouse (left column) and a DKO mouse (right column) stained for nNOS (top row), TpH (middle row), and $\mathrm{TH}$ (bottom row). Immunoreactivity appeared highly specific and the expected pools of labeled neurons were observed in sections from each genotype. No gross differences were observed in distribution of stained neurons or in the range of cell shapes in any of the receptor knockouts. This suggests that mesopontine cholinergic and monoaminergic neurons will be found in their expected locations and will be encountered at about the same rate in brain slice experiments from normal and receptor knockout mice. Of course, this qualitative observation does not rule out quantitative differences that might be present between knockout and wild type mice (see Kalogiannis et al., 2010; Valko et al., 2013).

\section{OREXIN-A PRODUCES COMPARABLE NOISY INWARD CURRENT IN SLICES FROM C57BL6 AND HYBRID BACKGROUND CONTROL MICE}

In our previous studies of orexin actions on LDT and DR neurons, we conducted whole-cell recordings and $\mathrm{Ca}^{2+}$ imaging using slices made from C57BL6 mice (Burlet et al., 2002; 


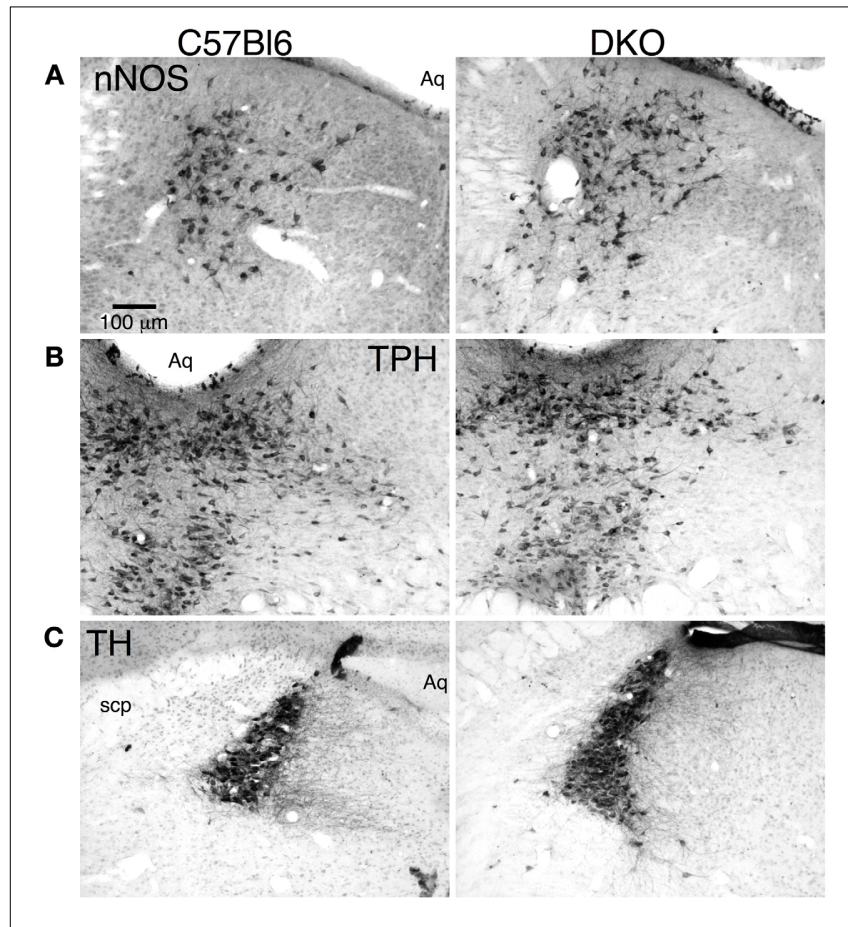

FIGURE 1 | Double orexin receptor knockout (DKO) mice showed grossly normal distributions of brainstem cholinergic and monoaminergic neurons. (A) nNOS immunolabeled sections through the caudal LDT stained with DAB from a C57BL6 mouse (left) and a DKO mouse (right). (B) TpH immunolabeled sections through the caudal DR stained with DAB from a C57BL6 mouse (left) and a DKO mouse (right). (C) $\mathrm{TH}$ immunolabeled sections through the LC stained with DAB from a C57BL6 mouse (left) and a DKO mouse (right). Abbreviations: Aq, Aqueduct; scp, superior cerebellar peduncle.

Kohlmeier et al., 2004, 2008). Since receptor null mice were on C57BL6/129SvEv hybrid background, we initially examined the ability of a bath application of orexin-A (300 nM) to evoke an inward current from a holding potential of $-60 \mathrm{mV}$ in LDT and DR neurons in slices from C57BL6 and background control mice (OxrWT). As expected, orexin-A activated a noisy inward current in both nuclei and this current appeared identical in both strains. In the LDT, we recorded 16 neurons from 13 C57BL6 mice and 7 neurons from 6 OxrWT mice. There was no difference in the mean current (C57BL6: $-19.1 \pm 2.4$ pA; OxrWT: $-15.2 \pm 3.1 \mathrm{pA} ; P=0.38)$ and there was no difference in the distribution of current amplitudes, including the three C57BL6 and two OxrWT neurons that didn't respond (Kolmogorov-Smirnov test, $P=0.24$ ). In the DR, we recorded 31 neurons from 22 C57BL6 mice and 16 neurons from 8 OxrWT mice. There was no difference in the mean current from cells that responded to orexin (C57BL6: $-36.3 \pm 2.9$ pA; OxrWT: $-36.9 \pm$ $3.2 \mathrm{pA} ; P=0.89$ ) and there was no difference in the distributions, including the one C57BL6 and two OxrWT neurons that didn't respond (Kolmogorov-Smirnov test, $P=1$ ). This suggests that the differences in genetic background of C57BL6 and hybrid mice has little influence on the expression of orexin currents.

\section{ACTIVATION OF OX 1 PRODUCES INWARD CURRENT AND ENHANCED $\mathrm{Ca}^{2+}$ TRANSIENTS IN LDT, DR, AND LC NEURONS}

To test the ability of $\mathrm{OX}_{1}$ to sustain orexin signaling in the LDT, $\mathrm{DR}$, and LC, we recorded from slices made from $\mathrm{OX}_{2}^{-/-}$mice and compared the orexin responses obtained in these knockouts with those in slices obtained from C57BL6 mice (Figure 2). In each nucleus, we examined the ability of a bath application of orexinA $(300 \mathrm{nM})$ to evoke an inward current from a holding potential of $-60 \mathrm{mV}$ and to enhance the $\mathrm{Ca}^{2+}$ influx produced by a voltagestep from -60 to $-30 \mathrm{mV}$.

In LDT neurons recorded from $\mathrm{OX}_{2}^{-/-}$mice, orexin-A evoked a slowly developing inward current, often with an increase in frequency and amplitude of sEPSPs (Figure $2 \mathbf{A}_{1}$; normal ACSF) that appeared quite similar to the responses previously described in nNOS+ LDT neurons (Burlet et al., 2002). We did not analyze the increase in sEPSC frequency in detail, but we compared the average magnitude of the slowly developing inward orexin current recorded from a holding potential of $-60 \mathrm{mV}$ (low-Ca ${ }^{2+}$ DABSTcontaining ACSF with Cs). This post-synaptic depolarizing current was $-40.7 \pm 13.0 \mathrm{pA}(n=7)$ which was not statistically different from the inward current measured from LDT neurons in slices from C57BL6 mice recorded under identical conditions $\left(32.8 \pm 10.6 \mathrm{pA} ; n=8 ; P>0.05\right.$; Figure $\left.2 \mathrm{D}_{1}\right)$. Orexin-A $(300 \mathrm{nM})$ also enhanced the $\mathrm{Ca}^{2+}$-transient evoked by a $5 \mathrm{~s}$ voltage-jump from -60 to $-30 \mathrm{mV}$ by $30.4 \pm 6.4 \%(n=9 / 12)$ in neurons from $\mathrm{OX}_{2}^{-/-}$mice (Figure $2 \mathrm{~A}_{2}$; DABST-containing ACSF). The magnitude of this $\mathrm{Ca}^{2+}$ transient enhancement was also not different from that measured in LDT neurons from C57BL6 mice $\left(31.1 \pm 7.7 \% ; n=9 / 13 ; P>0.05\right.$; Figure $\left.2 D_{2}\right)$.

In DR neurons recorded in slices from $\mathrm{OX}_{2}^{-/-}$mice, orexin $\mathrm{A}$ $(300 \mathrm{nM})$ also evoked a slow inward current (Figure $2 \mathbf{B}_{1}$; normal ACSF) as observed previously (Brown et al., 2002; Liu et al., 2002; Kohlmeier et al., 2008). These inward currents were not accompanied by increases in sEPSCs, as expected from a previous study (Haj-Dahmane and Shen, 2005). The average amplitude of the orexin-evoked slow inward current was $-55.2 \pm 14.4 \mathrm{pA}(n=$ 8; low-Ca ${ }^{2+}$ DABST-containing ACSF with Cs). This was not statistically different from the orexin-evoked current measured from DR neurons in slices from C57BL6 mice under the same conditions $\left(88.0 \pm 24.1 \mathrm{pA} ; n=7 ; P>0.05\right.$; Figure $\left.2 \mathrm{D}_{1}\right)$. In the voltage-step paradigm, orexin- $\mathrm{A}(300 \mathrm{nM})$ also enhanced the $\mathrm{Ca}^{2+}$-transient evoked by steps from -60 to $-30 \mathrm{mV}$ by $32.3 \pm$ $8.7 \%(n=13 / 18)$ in neurons from $\mathrm{OX}_{2}^{-/-}$mice (Figure $2 \mathrm{~A}_{2}$; DABST-containing ACSF) as reported in wild-type DR neurons (Kohlmeier et al., 2008). This enhancement in neurons from $\mathrm{OX}_{2}^{-1-}$ mice was also not different from that measured in DR neurons from C57BL6 mice $(28.6 \pm 3.5, n=9 / 14 ; P>0.05$; Figure $2 \mathrm{D}_{2}$ ) recorded under the same conditions.

In LC neurons from $\mathrm{OX}_{2}^{-/-}$mice, orexin-A (300 nM) produced a small, slow inward current (Figure $2 \mathrm{C}_{1}$; normal ACSF). The average current evoked by orexin-A was $11.4 \pm 1.2 \mathrm{pA}$ ( $n=$ 28; DABST-containing ACSF) and was not different from the average current measured from LC neurons in slices from C57BL6 mice under the same conditions $(12.4 \pm 1.8 \mathrm{pA} ; n=12 ; P>$ 0.05 ; Figure $\left.2 \mathrm{D}_{1}\right)$. Orexin-A $(300 \mathrm{nM})$ also produced a strong enhancement of the $\mathrm{Ca}^{2+}$ transient evoked by a voltage step 

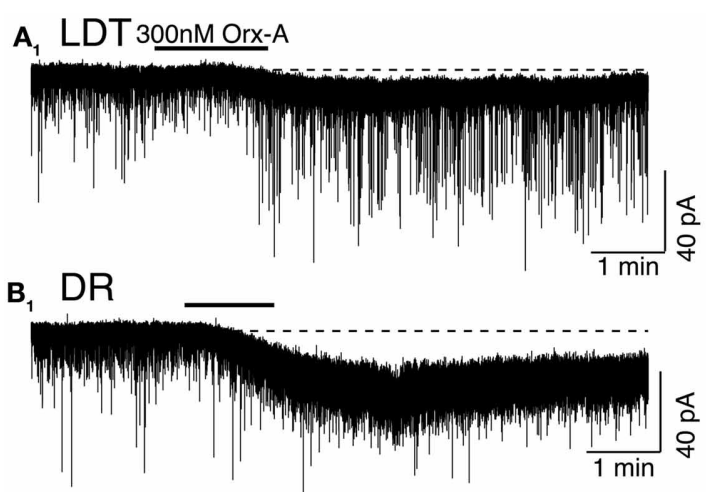

$\mathbf{A}_{2}$

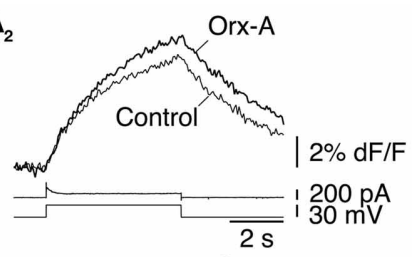

$\mathbf{B}_{2}$

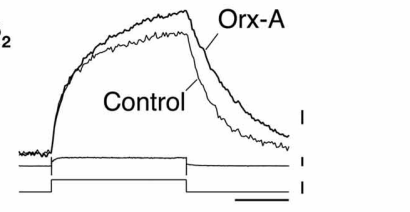

c LC
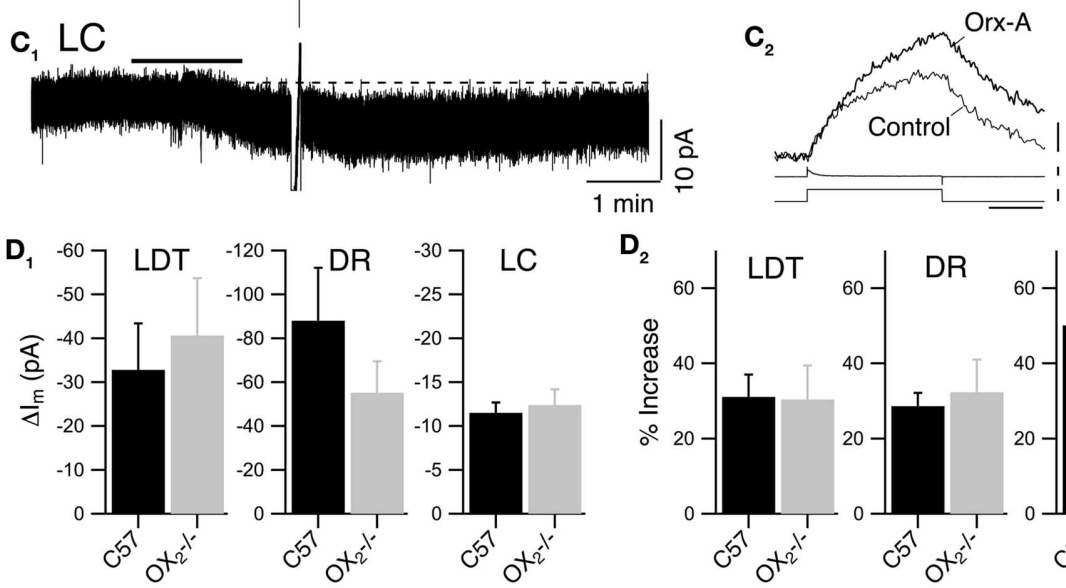

$\mathbf{D}_{2}$

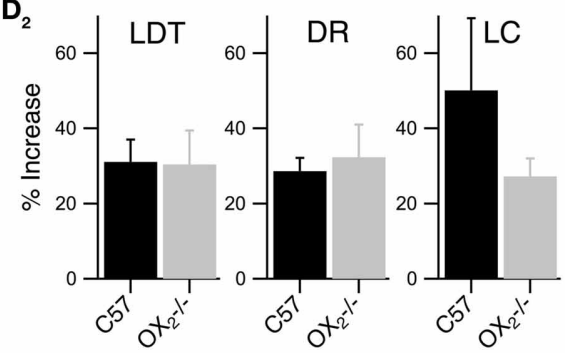

FIGURE 2 | Recordings from $\mathrm{OX}_{2}^{-/-}$slices indicate that $\mathrm{OX}_{1}$ is sufficient for orexin-mediated excitation and enhancement of voltage-dependent $\mathrm{Ca}^{2+}$ transients in LDT, DR, and LC neurons. (A) Whole-cell voltage clamp recording from LDT neurons in $\mathrm{OX}_{2}^{-1-}$ slices showed that $300 \mathrm{nM}$ orexin-A (Orx-A) still evoked an inward current with increased sEPSCs [holding potential: $-60 \mathrm{mV} ;\left(\mathbf{A}_{1}\right)$; normal ACSF] and also augmented the $\mathrm{Ca}^{2+}$ transients evoked by $5 \mathrm{~s}$ voltage-steps from -60 to $-30 \mathrm{mV}\left[\left(\mathbf{A}_{\mathbf{2}}\right)\right.$; DABST-containing ACSF]. (B) Voltage clamp recordings from DR neurons in $\mathrm{OX}_{2}^{-1-}$ slices showed that orexin-A evoked an inward [holding potential: $-60 \mathrm{mV}$; $\left(\mathbf{B}_{\mathbf{1}}\right)$; normal ACSF] and augmented $\mathrm{Ca}^{2+}$ transients [( $\left.\mathbf{B}_{\mathbf{2}}\right)$; DABST-containing ACSF]. (C) Voltage clamp recordings from $L C$ neurons in $\mathrm{OX}_{2}^{-1-}$ slices showed that orexin-A evoked an inward current [holding potential: $-60 \mathrm{mV} ;\left(\mathbf{C}_{1}\right)$; normal ACSF] and augmented $\mathrm{Ca}^{2+}$ transients $\left[\left(\mathbf{C}_{\mathbf{2}}\right)\right.$;

DABST-containing ACSF]. In $\left(\mathbf{A}_{1}, \mathbf{B}_{1}, \mathbf{C}_{1}\right)$, the horizontal bar indicates time of $300 \mathrm{nM}$ orexin-A superfusion. In $\left(\mathbf{A}_{\mathbf{2}}, \mathbf{B}_{\mathbf{2}}, \mathbf{C}_{\mathbf{2}}\right)$, top traces show somatic $\mathrm{Ca}^{2+}$-dependent fluorescence $(\mathrm{dF} / \mathrm{F})$; Middle traces show whole-cell current; Bottom traces show membrane voltage. Calibration bars indicate $2 \% \mathrm{dF} / \mathrm{F}$, $200 \mathrm{pA}, 30 \mathrm{mV}$, and $2 \mathrm{~s}$. (D) Neither the orexin-evoked inward current nor the orexin-enhanced voltage-dependent $\mathrm{Ca}^{2+}$ transients was different in neurons from $\mathrm{OX}_{2}^{-1-}$ slices compared to wild-type slices. Comparison by nuclei of the mean \pm SEM of the post-synaptic inward current $\left[\left(\mathbf{D}_{\mathbf{1}}\right)\right.$; LDT and DR recorded in low-Ca ${ }^{2+}$ DABST-containing ACSF with Cs; $L C$ recorded in DABST-containing ACSF] and mean \pm SEM of the $\mathrm{Ca}^{2+}$ transient enhancement [ $\left(\mathbf{D}_{\mathbf{2}}\right)$; DABST-containing ACSF] produced by orexin-A in neurons recorded from $\mathrm{OX}_{2}^{-1-}$ slices and C57BL6 slices under the same conditions.

from -60 to $-30 \mathrm{mV}$ (Figure $2 \mathrm{C}_{2}$; DABST-containing ACSF) in LC neurons. This enhancement was on average $27.2 \pm 4.8 \%$ $(n=11 / 17)$ and was not different from that obtained from LC neurons from C57BL6 mice $(50.19 \pm 19.1 \% ; n=6 / 8 ; P>0.05$; Figure $2 \mathrm{D}_{2}$ ) recorded under the same conditions. Collectively, these data indicate that $\mathrm{OX}_{1}$ is sufficient to mediate two normal actions of orexin on LDT, DR, and LC neurons: (1) post-synaptic activation of a slowly developing inward current and (2) the enhancement of voltage-dependent $\mathrm{Ca}^{2+}$ influx.

To determine if $\mathrm{OX}_{1}$ mediated these actions in principal neurons from each nucleus, we processed brain slices from $\mathrm{OX}_{2}^{-/-}$ mice for immunocytochemistry to identify the transmitter phenotype of recorded neurons. In the LDT, we confirmed that $\mathrm{OX}_{1}$ activation produced an inward current in six nNOS+ neurons and that $\mathrm{OX}_{1}$ activation enhanced the voltage-step evoked $\mathrm{Ca}^{2+}$ transient in four nNOS+ neurons. In the DR, we confirmed that $\mathrm{OX}_{1}$ activation produced an inward current in nine $\mathrm{TpH}+$ neurons and enhanced the voltage-step evoked $\mathrm{Ca}^{2+}$ transient in four $\mathrm{TpH}+$ neurons. Similarly, in the LC, we confirmed that $\mathrm{OX}_{1}$ activation produced an inward current in $24 \mathrm{TH}+$ neurons and enhanced the voltage-step evoked $\mathrm{Ca}^{2+}$ transient in $2 / 4 \mathrm{TH}+$ neurons. Figure 3 illustrates examples of an nNOS+ neuron recorded in the LDT (Figure 3A), a $\mathrm{TPH}+$ neuron recorded in the $\mathrm{DR}$ (Figure 3B) and a $\mathrm{TH}+$ neuron recorded in the LC. Each of these neurons showed an $\mathrm{OX}_{1}$-mediated inward current and an enhancement of the $\mathrm{Ca}^{2+}$ transient evoked by voltage steps from -60 to $-30 \mathrm{mV}$. From these data we conclude that $\mathrm{OX}_{1}$ is sufficient to mediate major direct orexin actions on principal cells of these nuclei. 

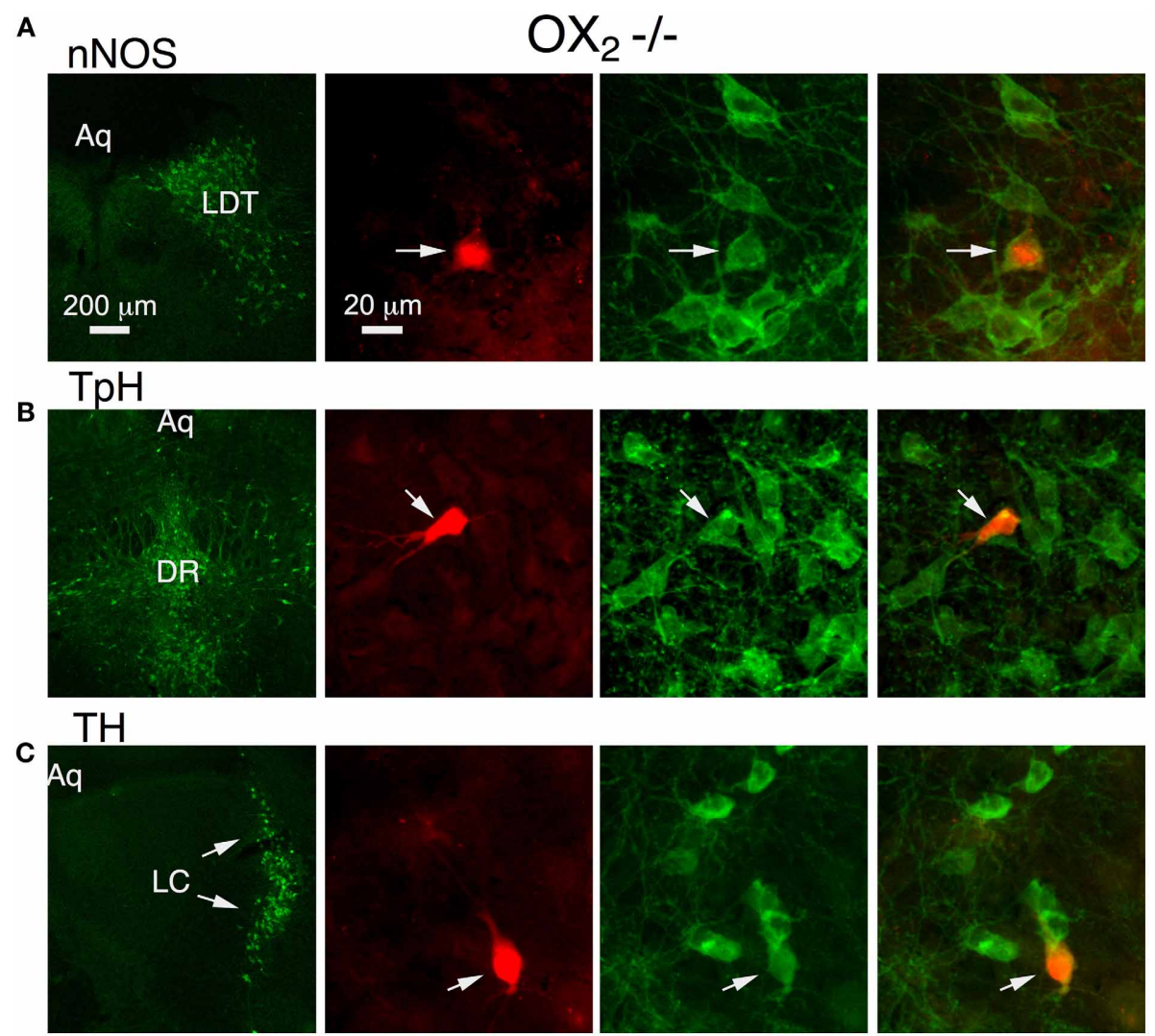

FIGURE 3 | Stimulation of $\mathrm{OX}_{1}$ alone is sufficient to produce inward currents and augmented voltage-dependent $\mathrm{Ca}^{2+}$ transients in nNOS+ LDT neurons (A), TpH+ DR neurons (B), and TH+ LC neurons (C). Left column illustrates low-power fluorescent micrographs of the recorded slices immunostained and visualized with an Alexa-488-label (green) for nNOS in LDT (A), TpH in DR (B), and TH in the LC (C). The second column illustrates a higher-power image of the recorded and red fluorescently labeled neuron (arrow; Alexa 594) in each nucleus. The third column shows the same field with Alexa 488 visualized. The right column merges the Alexa 488 and 594 images and indicates that each recorded neuron was immunopositive for nNOS, $\mathrm{TpH}$, and $\mathrm{TH}$, respectively.

\section{$\mathrm{OX}_{1}$ ACTIVATES A NOISY CATION CURRENT IN LDT AND DR NEURONS AND ENHANCES $\mathrm{Ca}^{2+}$ TRANSIENTS MEDIATED BY L-TYPE $\mathrm{Ca}^{2+}$ CHANNELS IN LDT, DR, AND LC NEURONS}

As noted above, previous studies of LDT and DR neurons indicate that a noisy non-selective cation current is an important effector mediating the slow membrane depolarization produced by orexin-A. We therefore examined the change in membrane noise and the current-voltage relation of the current evoked in LDT and DR neurons from $\mathrm{OX}_{2}^{-/-}$mice to determine if $\mathrm{OX}_{1}$ is competent to activate a similar current. Since current evoked by orexin-A in LC neurons was quite small in our recordings, and since they did not show a similar increase in noise, we did not further characterize their orexin currents. In both LDT (Figure $4 A_{1}$ ) and DR (Figure $4 B_{1}$ ) neurons from $\mathrm{OX}_{2}^{-/-}$ mice, orexin-A $(300 \mathrm{nM})$ produced an inward current that was accompanied by a large increase in membrane current noise, similar to that reported in wild-type mice (Kohlmeier et al., 2008). The membrane current noise increased by $118.4 \pm 59.3 \%$ in LDT neurons $(n=8)$ and by $307 \pm 87.0 \%$ in DR neurons $(n=7)$ which was not different from values in LDT $(86.8 \pm$ $31.3 \%, n=8 ; P>0.05)$ and DR $(380.5 \pm 85.2 \% ; n=7 ; P>$
0.05) from C57BL6 mice. Similarly, the I-V relation for the orexin mediated current in LDT (Figure $4 \mathrm{~A}_{2}$ ) and DR neurons (Figure $4 \mathbf{B}_{2}$ ) from $\mathrm{OX}_{2}^{-/-}$mice was computed from voltage ramps between -100 and $-35 \mathrm{mV}$. It appeared roughly linear over this range as previously described for C57BL6 neurons in these nuclei (Kohlmeier et al., 2008) suggesting that $\mathrm{OX}_{1}$ activates the same channel or channels that are activated in C57BL6 mice.

In LDT and DR neurons from C57BL6 mice, the orexin mediated enhancement of voltage-dependent $\mathrm{Ca}^{2+}$ transients produced by voltage-steps from -60 to $-30 \mathrm{mV}$ is produced almost entirely by the enhancement of $\mathrm{Ca}^{2+}$ transients generated by L-type $\mathrm{Ca}^{2+}$ channels (Kohlmeier et al., 2008). We therefore tested whether the L-channel antagonist nifedipine (10 $\mu \mathrm{M})$, also occludes this enhancement in LDT, DR, and LC neurons in slices from $\mathrm{OX}_{2}$ mice. Nifedipine alone, attenuated the $\mathrm{Ca}^{2+}$ transient produced by a voltage-step from -30 to $-60 \mathrm{mV}$ in LDT (Figure 4C), DR (Figure 4D), and LC (Figure 4E) neurons indicating that activation of L-type channels contribute to these transients. In the presence of nifedipine, orexin failed to significantly enhance the calcium transient in all cells examined 

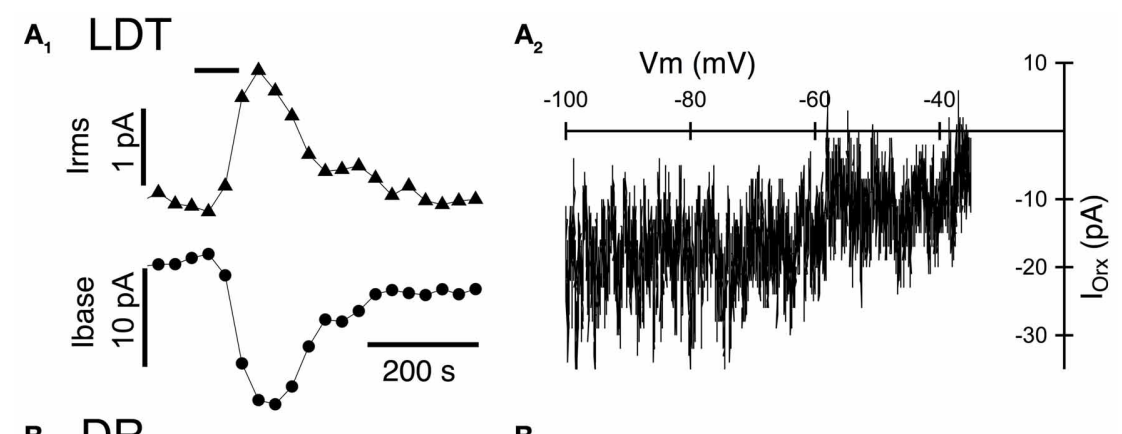

B, DR
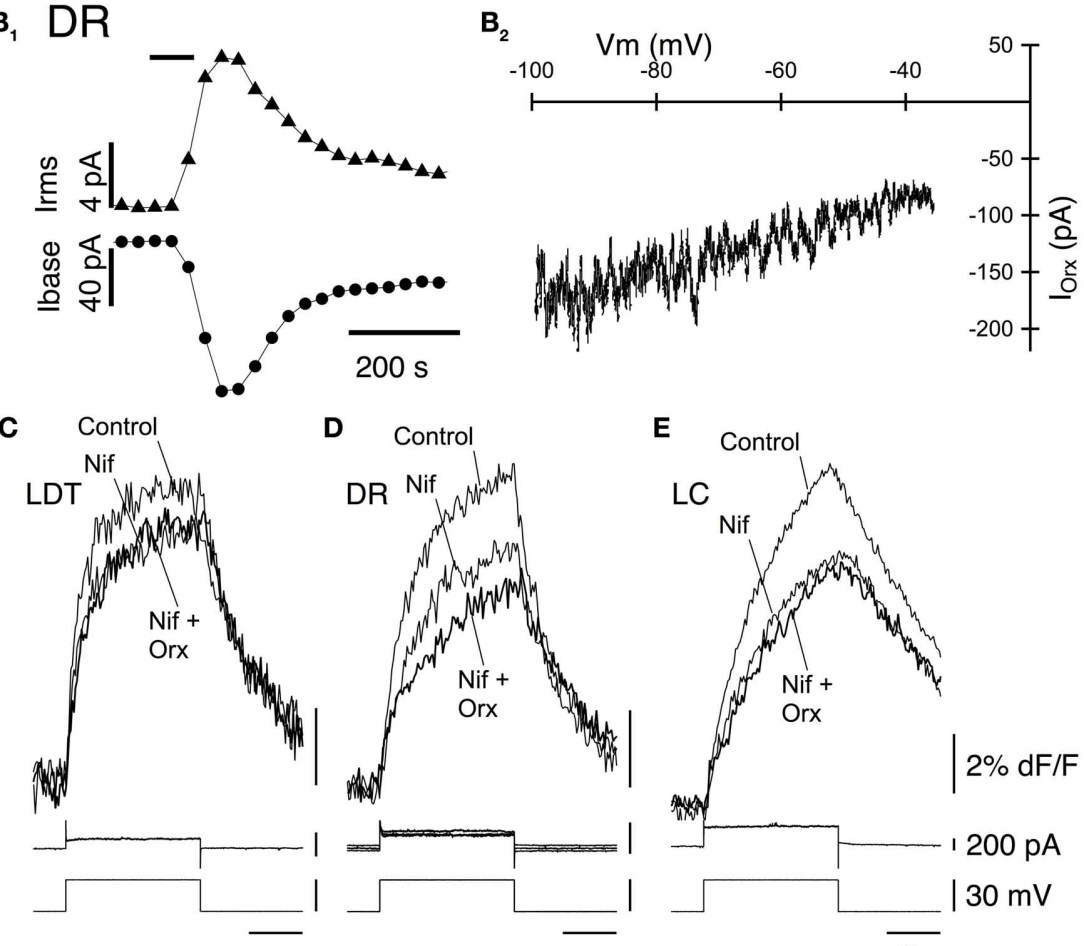

D Contro

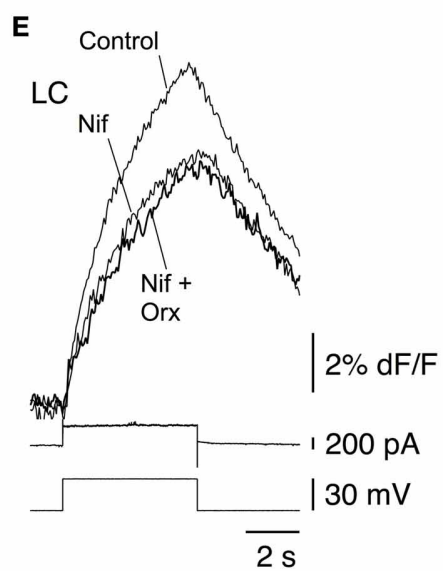

FIGURE 4 | Stimulation of $\mathrm{OX}_{1}$ alone activates a noisy cation current in LDT and DR neurons and enhance voltage-dependent $\mathrm{Ca}^{2+}$ transients mediated by L-type $\mathrm{Ca}^{2+}$ channels in LDT, DR, and LC neurons. $\left(\mathrm{A}_{1}\right)$ Holding current (at $-60 \mathrm{mV}$; Ibase; bottom trace) and membrane current noise (Irms; top trace) were measured every $30 \mathrm{~s}$ starting before bath application of $300 \mathrm{nM}$ orexin-A (horizontal bar) from LDT neurons in $\mathrm{OX}_{2}^{-1-}$ slices. Orexin produced an inward shift in holding current that was accompanied by an increase in current noise. $\left(\mathbf{A}_{\mathbf{2}}\right)$. The I-V curve of the orexin-evoked inward current (lorx) was obtained by subtracting the membrane current produced by a voltage ramp between -100 and $-35 \mathrm{mV}$ prior to orexin-A application from that obtained during the peak of the orexin-A-evoked inward current. These currents were similar to those obtained from LDT neurons in C57BL6 slices. $\left(\mathbf{B}_{\mathbf{1}}\right)$ Orexin-A $(300 \mathrm{nM})$ has a similar, but larger effect on the holding current (Ibase, bottom) and membrane current noise (Irms, top) in DR neurons recorded in $\mathrm{OX}_{2}^{-1-}$ slices. $\left(\mathbf{B}_{\mathbf{2}}\right)$ The I-V relation for the orexin-evoked inward current $\left(\mathrm{I}_{\mathrm{OrX}}\right)$ in a DR neuron from an $\mathrm{OX}_{2}^{-/-}$slice was similar that that observed in DR neurons from C57BL6 slices. (C,D,E). The L-channel antagonist, nifedipine (Nif, $10 \mu \mathrm{M})$ attenuated the $\mathrm{Ca}^{2+}$-transients evoked by voltage-steps from -60 to $-30 \mathrm{mV}$ in LDT (C), DR (D), and LC (E) neurons from $\mathrm{OX}_{2}^{-1-}$ slices and completely blocked the enhancement of these transients by orexin-A ( $300 \mathrm{nM}$ ). Top traces show somatic $\mathrm{Ca}^{2+}$-dependent fluorescence (dF/F); Middle traces show whole-cell current; Bottom traces show membrane voltage. Calibration bar labels in (E), also apply to (C) and (D) within the LDT, DR, or LC (LDT: 9\% reduction in the transient, $P>0.05 . n=4$; DR: $5.2 \%$ reduction in the transient, $P>0.05$, $n=4 ; \mathrm{LC}: 1.8 \%$ increase in the transient, $P>0.05, n=4)$. These data suggest that the $\mathrm{Ca}^{2+}$ transients augmented by $\mathrm{OX}_{1}$ signaling are mediated by enhanced influx via L-type $\mathrm{Ca}^{2+}$ channels. Thus, activation of $\mathrm{OX}_{1}$ alone is sufficient to activate a noisy cation current in LDT and DR neurons and to enhance $\mathrm{Ca}^{2+}$ transients which appear generated by L-type $\mathrm{Ca}^{2+}$ channels in the LDT, DR, and LC.

\section{ACTIVATION OF OX ${ }_{2}$ EXCITES DR NEURONS AND ENHANCES $\mathrm{Ca}^{2+}$ TRANSIENTS IN LDT, DR, AND LC NEURONS}

To determine whether activation of $\mathrm{OX}_{2}$ alone can influence membrane currents and $\mathrm{Ca}^{2+}$ transients in LDT, DR, and LC neurons, we examined the action of orexin-A in slices prepared from mice lacking $\mathrm{OX}_{1}$. Whole-cell recordings from LDT $(n=14)$ and LC $(n=45)$ neurons revealed that in that absence of $\mathrm{OX}_{1}, 300 \mathrm{nM}$ orexin-A failed to induce a detectable inward current at a holding potential of $-60 \mathrm{mV}$ (Figures $5 \mathbf{A}_{1}, \mathbf{C}_{1}$ ). 


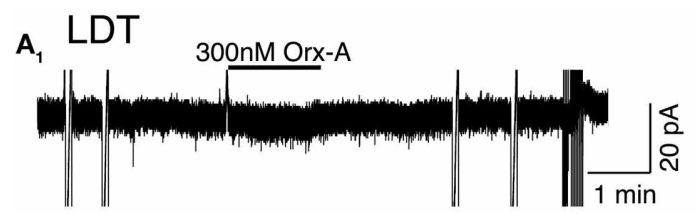

B DR

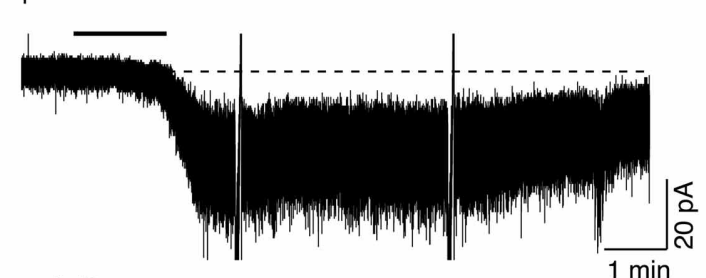

c LC

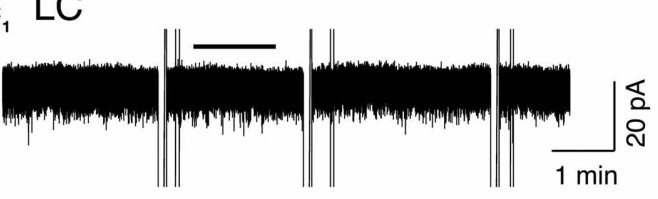

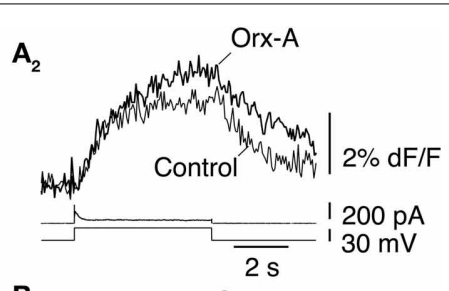

$\mathbf{B}_{2}$
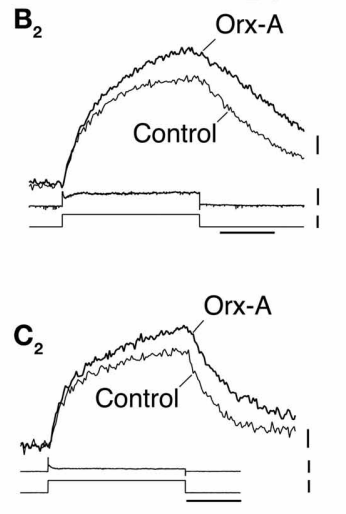

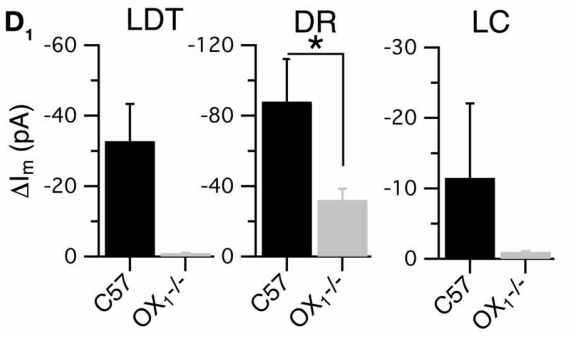

FIGURE 5 | Stimulation of $\mathrm{OX}_{2}$ alone is sufficient to produce an inward current in DR neurons and to enhance voltage-dependent $\mathrm{Ca}^{2+}$ transients in LDT, DR, and LC neurons. (A) Whole-cell voltage clamp recordings obtained from LDT neurons in $\mathrm{OX}_{1}^{-/-}$slices showed that $300 \mathrm{nM}$ orexin-A (Orx-A) failed to evoke a current at $-60 \mathrm{mV}\left(\mathbf{A}_{\mathbf{1}}\right)$ but augmented voltage-dependent $\mathrm{Ca}^{2+}$ transients evoked by $5 \mathrm{~s}$ voltage-steps from -60 to $-30 \mathrm{mV}\left(\mathbf{A}_{\mathbf{2}}\right)$. (B) Voltage clamp recordings obtained from DR neurons in $\mathrm{OX}_{1}^{-/-}$slices showed that orexin-A evoked both a noisy inward current (holding potential: $-60 \mathrm{mV} ; \mathbf{B}_{\mathbf{1}}$ ) and augmented voltage-dependent $\mathrm{Ca}^{2+}$ transients $\left(\mathbf{B}_{\mathbf{2}}\right)$. (C) Voltage clamp recordings obtained from $L C$ neurons in $\mathrm{OX}_{1}^{-/-}$slices showed that orexin-A failed to evoke an inward current (holding

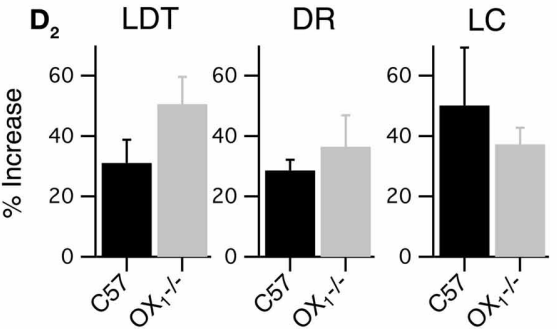

potential: $-60 \mathrm{mV} ; \mathbf{C}_{\mathbf{1}}$ ) but augmented voltage-dependent $\mathrm{Ca}^{2+}$ transients $\left(\mathbf{C}_{\mathbf{2}}\right)$. In $\left(\mathbf{A}_{\mathbf{1}}, \mathbf{B}_{\mathbf{1}}, \mathbf{C}_{\mathbf{1}}\right)$, the horizontal bar indicates time of $300 \mathrm{nM}$ orexin-A superfusion. In $\left(\mathbf{A}_{\mathbf{2}}, \mathbf{B}_{\mathbf{2}}, \mathbf{C}_{\mathbf{2}}\right)$, Top traces show somatic $\mathrm{Ca}^{2+}$-dependent fluorescence (dF/F); Middle traces show whole-cell current; Bottom traces show membrane voltage. Calibration bars indicate $2 \% \mathrm{dF} / \mathrm{F}, 200 \mathrm{pA}, 30 \mathrm{mV}$ and $2 \mathrm{~s}$. (D) The orexin-A evoked inward current was absent in LDT and LC neurons and was significantly smaller in DR neurons from $\mathrm{OX}_{1}^{-/-}$slices than in DR neurons from C57BL6 slices $\left(\mathbf{D}_{\mathbf{1}} ;{ }^{*} P<0.05\right)$. In contrast, the magnitude of the $\mathrm{Ca}^{2+}$ transient enhancement produced by orexin-A was the same in LDT, DR, and LC neurons from $\mathrm{OX}_{1}^{-/-}$slices compared to those recorded in C57BL6 slices.
In contrast, orexin-A application to DR neurons resulted in significant inward current with a large increase in membrane noise (Figure $\mathbf{5 B}_{1}$ ). Nevertheless, the average peak inward current elicited by orexin-A in DR neurons (32.2 $\pm 6.3 \mathrm{pA} ; n=8)$ was significantly lower than observed in control recordings from DR neurons in slices from C57BL6 mice $(88.0 \pm 24.1 \mathrm{pA} ; n=7$; $P<0.05$; Figure $5 \mathrm{D}_{1}$ ).

Despite being unable to stimulate inward currents in LDT and $\mathrm{LC}$ neurons from $\mathrm{OX}_{1}^{-/-}$mice, orexin-A was effective at enhancing $\mathrm{Ca}^{2+}$ transients evoked by voltage-jumps from -60 to $-30 \mathrm{mV}$ in LDT, DR and LC neurons (Figures $\mathbf{5} \mathbf{A}_{2}, \mathbf{B}_{2}, \mathbf{C}_{2}$ ). In fact, on average the magnitude of the enhancement in the absence of $\mathrm{OX}_{1}$ (LDT: $50.6 \pm 9.0 \%, n=7 / 17$; DR: $36.5 \pm 10.4$, $n=11 / 18$; LC: $37.3 \pm 5.5, n=8 / 13)$ was as large as observed in control neurons from C57BL6 mice (Figure 5D $2 ; P>0.05$ for each cell type). In a some recordings, we were able to verify that the recorded neurons were nNOS+ in the LDT $(n=$ $6), \mathrm{TpH}+$ in the $\mathrm{DR}(n=9)$, and $\mathrm{TH}+$ in the LC $(n=13$; Figure 6). This confirmed that $\mathrm{OX}_{2}$ alone is insufficient to excite neurons in the LDT and LC at subthreshold membrane potentials but is sufficient to do so in $\mathrm{TpH}+\mathrm{DR}$ neurons. In spite of this, $\mathrm{OX}_{2}$ activation is able to augment the step-activated $\mathrm{Ca}^{2+}$ transients in principal neurons of each of these nuclei. This implies that released orexin would enhance $\mathrm{Ca}^{2+}$ influx during persistent activity in each nucleus, even in $\mathrm{OX}_{1}$ null mice.

We also examined the $\mathrm{I}-\mathrm{V}$ relation between -100 and $-30 \mathrm{mV}$ in LDT and DR neurons. This confirmed that no observable subthreshold currents were activated by orexin-A in LDT neurons (Figures $7 \mathbf{A}_{1}, \mathbf{A}_{2}$ ) and that the noisy inward current activated in 

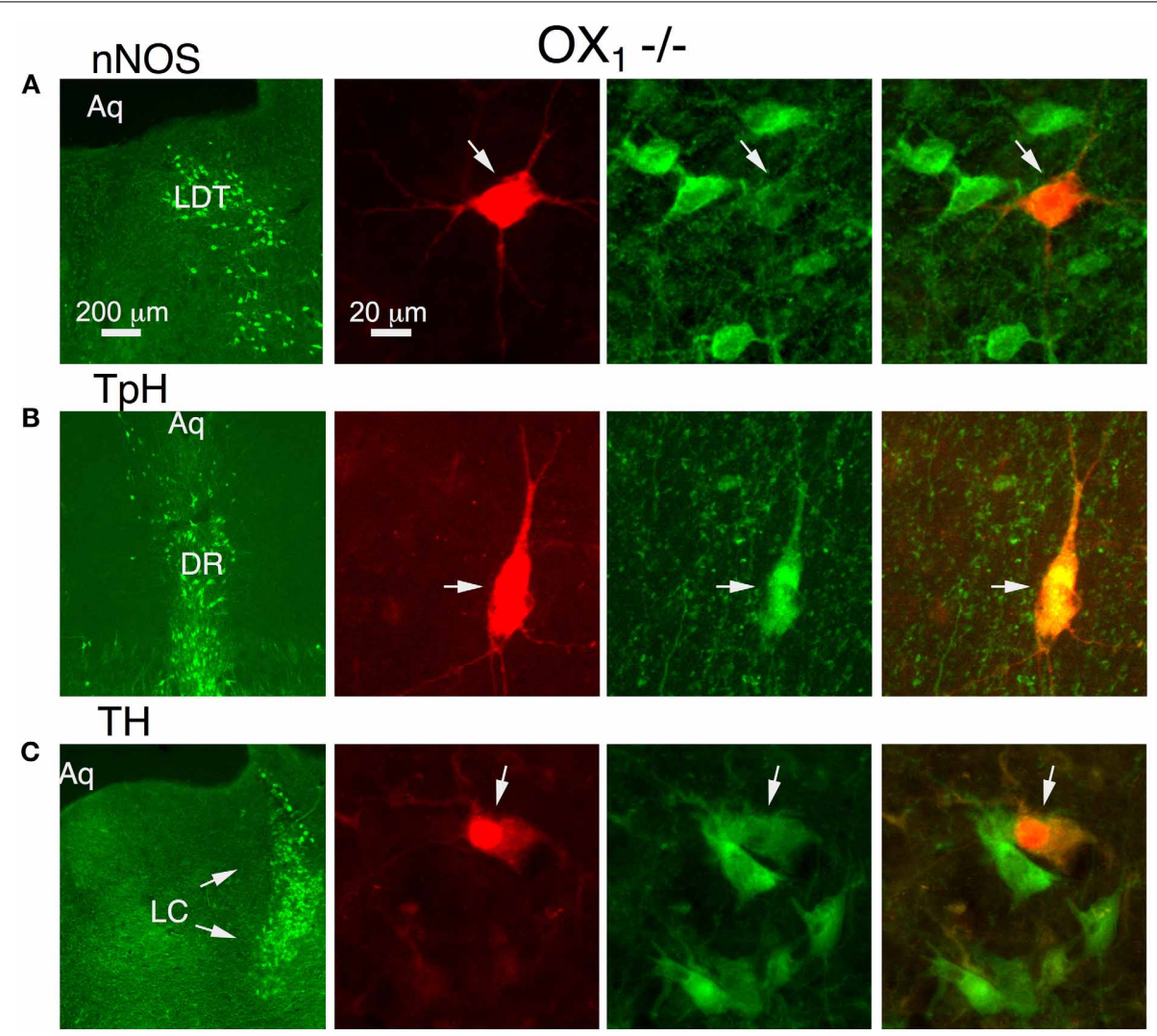

FIGURE 6 | Orexin augments voltage-dependent $\mathrm{Ca}^{2+}$ transients in nNOS+ LDT neurons, TpH+ DR neurons, and TH+ LC neurons in slices from $\mathbf{O X}_{\mathbf{1}}^{-1-}$ mice. Orexin-A augmented the voltage-dependent $\mathrm{Ca}^{2+}$ transient in identified neurons. Left column illustrates low-power fluorescent micrographs of the recorded slices immunostained with Alexa-488 (green) for nNOS in LDT (A), TpH in DR (B), and TH in the
LC (C arrows). The second column illustrates a higher-power image of the recorded and fluorescently labeled neurons (Alexa-594) from each nucleus. The third column shows the same field with Alexa-488 visualized. The right column shows the images merged, revealing that each recorded neuron was immunopositive for nNOS, $\mathrm{TpH}$, and $\mathrm{TH}$, respectively.
DR neurons was approximately linear over this voltage range, having similar characteristics to the non-selective cation current observed in C57BL6 DR neurons (Figures $7 \mathbf{B}_{1}, \mathbf{B}_{2}$ ). Similarly, we determined whether L-type $\mathrm{Ca}^{2+}$ channels are a target of $\mathrm{OX}_{2}$ by testing whether nifedipine occluded the orexin-A enhancement of $\mathrm{Ca}^{2+}$ transients (Figures 7C,D,E). In LDT, DR, and LC neurons obtained from mice lacking $\mathrm{OX}_{1}$, nifedipine blocked the enhancement produced by orexin-A (300 nM) application. In the presence of nifedipine, orexin-A application produced a $0.6 \pm 0.4 \%$ increase in LDT $(n=4)$, a $4.0 \pm 2.1 \%$ increase in DR $(n=5)$ and a $3.6 \pm 3.3 \%$ increase in LC neurons $(n=6)$. These changes were not significantly different from zero $(P>0.05)$ and all of these differences were significantly less than changes produced in neurons from C57BL6 mice $(P<0.05)$. Thus, activation of $\mathrm{OX}_{2}$ alone is sufficient to activate a noisy cation current in DR neurons but not in LDT or LC neurons. Despite this, $\mathrm{OX}_{2}$ activation is sufficient to enhance $\mathrm{Ca}^{2+}$ transients in the LDT, DR, and LC. Moreover, the magnitude of this enhancement was comparable to the enhancement measured in LDT, DR, and LC neurons from C57BL6 mice and also appear mediated by L-type $\mathrm{Ca}^{2+}$ channels.

\section{OX ${ }_{1}$ SIGNALING IS DOMINANT IN THE LDT AND LC BUT IS MORE EVENLY SHARED BY BOTH RECEPTORS IN THE DR}

To obtain a better estimate of the fraction of neurons activated by each orexin receptor, we utilized fura-2AM loading of slices obtained from mice lacking each receptor (Figure 8). Under these conditions, orexin-A $(300 \mathrm{nM})$ evokes $\mathrm{Ca}^{2+}$ transients by both depolarization and subsequent activation of a voltage-dependent $\mathrm{Ca}^{2+}$ influx and by specific enhancement of the $\mathrm{Ca}^{2+}$ transient evoked by L-type $\mathrm{Ca}^{2+}$ channel activation (Kohlmeier et al., 2004, 2008). As expected from whole-cell $\mathrm{Ca}^{2+}$ transient measurements, $300 \mathrm{nM}$ orexin-A evoked $\mathrm{Ca}^{2+}$ transients in slices obtained from mice lacking $\mathrm{OX}_{2}$ (Figure 8A) and mice lacking $\mathrm{OX}_{1}$ (Figure 8B). We found that in each genotype and nucleus, these transients recapitulated the range of temporal profiles we observed in DR and LDT slices from C57BL6 mice (Kohlmeier et al., 2004). Moreover, when the magnitude of the "plateau" type $\mathrm{Ca}^{2+}$ responses, which we could confidently measure, were compared, the transients from knockout slices were not smaller than the transients from C57BL6 slices. In $\mathrm{OX}_{2}$ null tissue, the average plateau responses were $11.9 \pm 1.8 \%$ in LDT $(n=13) ; 9.9 \pm 1.9 \%$ in DR $(n=18)$; and $12.1 \pm 2.4 \%$ in LC 

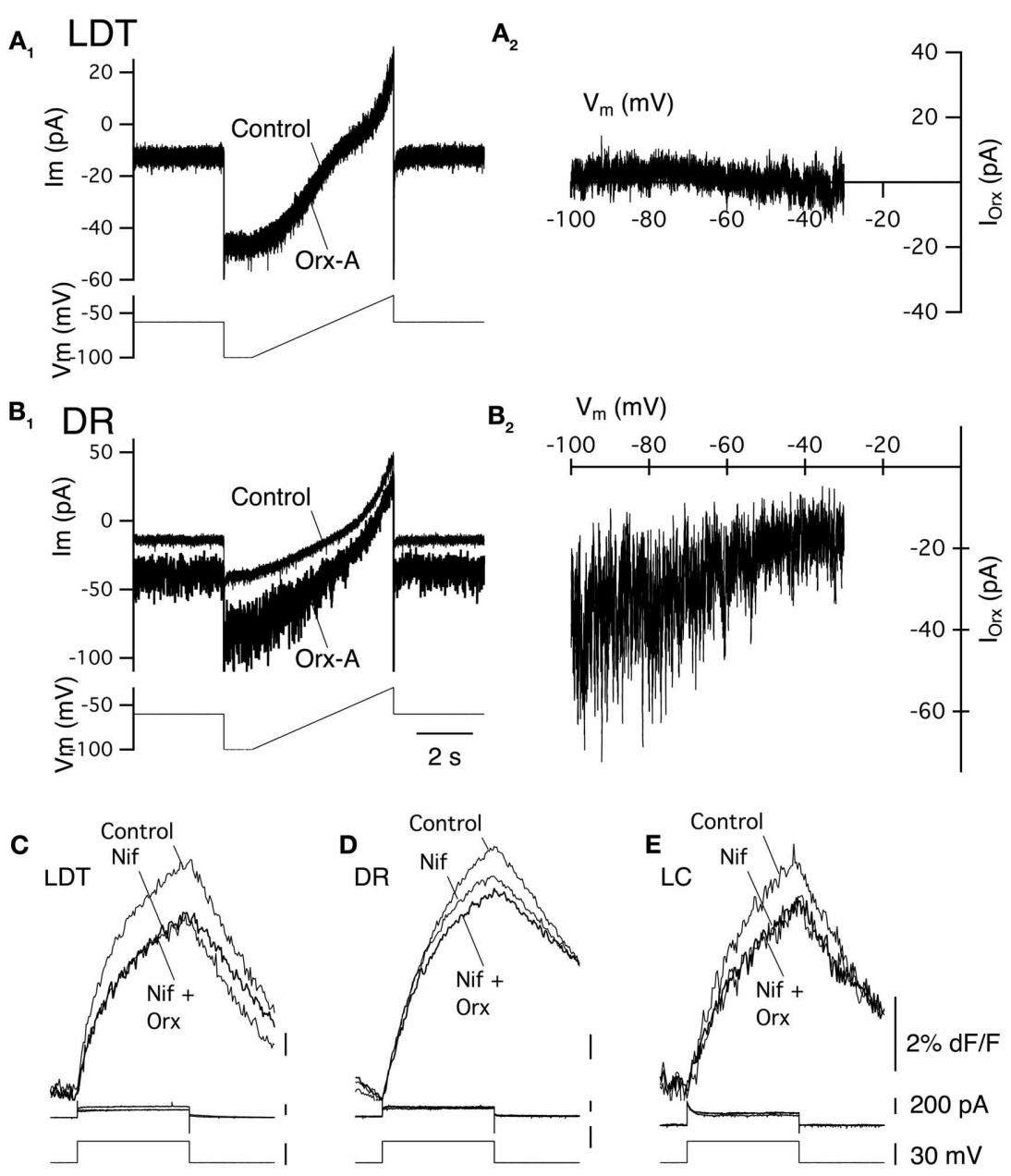

FIGURE 7 | Stimulation of $\mathrm{OX}_{2}$ alone activate a noisy cation current in DR neurons and enhance $\mathrm{Ca}^{2+}$ transients mediated by L-type $\mathrm{Ca}^{2+}$ channels in LDT, DR, and LC neurons. $\left(\mathrm{A}_{\mathbf{1}}\right)$ Whole-cell voltage clamp currents (upper traces) from an LDT neuron in an $\mathrm{OX}_{1}^{-/-}$slice recorded before and after bath superfusion with orexin-A (Orx-A, $300 \mathrm{nM})$. These currents were produced by the voltage-ramp in the bottom trace $(-100$ to $-35 \mathrm{mV})$. Orexin failed to produce an inward shift in holding current in LDT neurons from $\mathrm{OX}_{1}^{-1-}$ mice. $\left(\mathbf{A}_{\mathbf{2}}\right)$ The difference between the currents in $\left(\mathbf{A}_{\mathbf{1}}\right)$ plotted as a function of membrane voltage $(\mathrm{Vm})$ shows the $\mathrm{I}-\mathrm{V}$ relation. No orexin current was detectable throughout the voltage range studied. $\left(\mathbf{B}_{1}\right)$ Orexin- $\mathbf{A}(300 \mathrm{nM})$ produced an inward shift in holding current and a large increase in membrane current noise in DR neurons recorded in $\mathrm{OX}_{1}^{-1-}$ slices. $\left(\mathbf{B}_{\mathbf{2}} \mathbf{)}\right.$ The I-V relation for the difference current from $\left(\mathbf{B}_{1}\right)$ appeared nearly linear and was characteristic of the cation current observed in DR neurons from C57BL6 slices. (C,D,E) The L-channel antagonist, nifedipine (Nif, $10 \mu \mathrm{M}$ ) attenuated the $\mathrm{Ca}^{2+}$-transients evoked by voltage-steps from -60 to $-30 \mathrm{mV}$ in LDT (C), DR (D), and LC (E) neurons from $\mathrm{OX}_{1}^{-1-}$ slices and prevented the enhancement of these transients by orexin-A $(300 \mathrm{nM})$. Top traces show somatic $\mathrm{Ca}^{2+}$-dependent fluorescence $(\mathrm{dF} / \mathrm{F})$; Middle traces show whole-cell current; Bottom traces show membrane voltage. Calibration bar labels in (E), also apply to (C,D). $(n=12)$, which were not different $(P>0.05)$ from responses measured in slices from C57BL6 mice $(11.0 \pm 2.2 \%$ in LDT, $n=29 ; 13.8 \pm 2.6 \%$ in DR, $n=49$; and $12.7 \pm 2.3 \%$ in LC, $n=24)$. Similarly, in $\mathrm{OX}_{1}$ null slices, the average plateau response were not different $(P>0.05)$ from those in C57BL6 slices $\left(\mathrm{OX}_{1}\right.$ null responses: $12.0 \pm 4.3 \%$ in $\mathrm{LDT}, n=12 ; 16.1 \pm 2.5 \%$ in DR, $n=15$; and $15.1 \pm 5.1 \%$ in LC, $n=5$ ). However, the likelihood of encountering orexin-A responsive cells (Figure 8C) was much lower in slices from $\mathrm{OX}_{1}$ null mice in both the LDT and LC. The proportion of fura-2AM labeled cells responding to orexin was only $20 \%$ in LDT $(n=113)$ and $10 \%$ in LC $(n=82)$ compared to estimates of $60-70 \%$ responding in slices from C57BL6 mice. Interestingly, in the DR from $\mathrm{OX}_{1}$ null mice, the fraction of responders was only reduced to $47.1 \%$ from about $70 \%$ in the C57BL6 mice. Presumably this high percent responding in the DR reflects the ability of $\mathrm{OX}_{2}$ to drive depolarizations in DR neurons unlike in LDT and LC neurons.

\section{OX ${ }_{1}$ AND OX ${ }_{2}$ SIGNALING IS ATTENUATED BY PKC INHIBITION}

In the next series of experiments we examined whether the PKC inhibitor Bis I attenuates the $\mathrm{Ca}^{2+}$ transients evoked by activity of one or both receptors. In these experiments, we first obtained control responses with bath application of orexin-A 


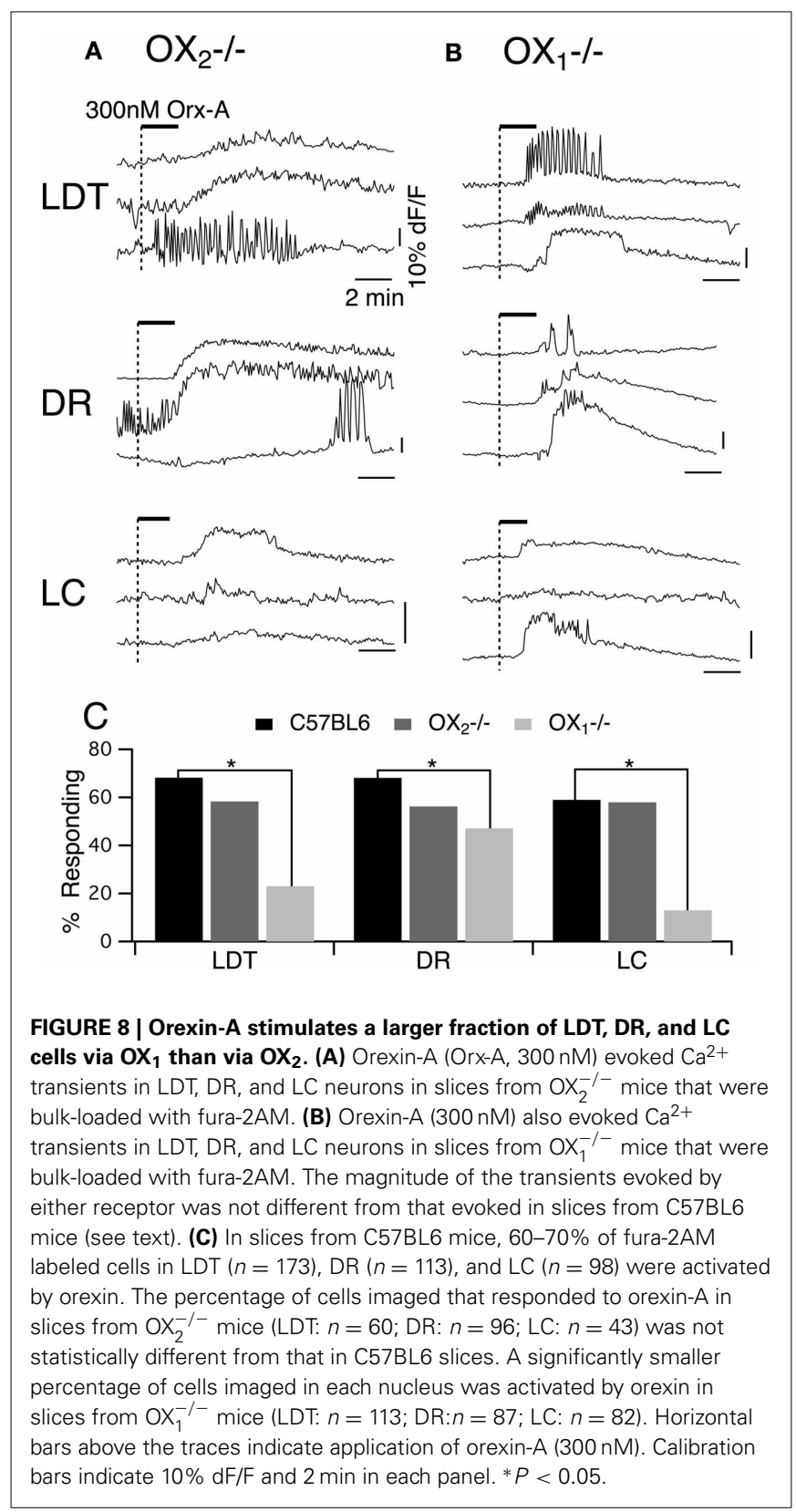

$(300 \mathrm{nM})$ from $\mathrm{OX}_{2}^{-/-}$or $\mathrm{OX}_{1}^{-/-}$slices containing LDT, DR, or LC (Figures 9, left column in A,B). The slices were then superfused with ACSF containing bis I ( $1 \mu \mathrm{M}$; Bis) for $20 \mathrm{~min}$, to inhibit PKC. This completely attenuated the orexin-mediated enhancement of L-type $\mathrm{Ca}^{2+}$ transients but did not block the orexin mediated depolarization in all LDT and DR neurons (Kohlmeier et al., 2008). Here, we found that the $\mathrm{Ca}^{2+}$ transients evoked in each nucleus were strongly attenuated by Bis in slices from both $\mathrm{OX}_{2}$ and $\mathrm{OX}_{1}$ null mice (Figures 9, right column in $\mathbf{A}, \mathbf{B})$. The average amplitude of plateau responses was reduced by $62.0 \pm 7.7 \%$ in slices from $\mathrm{OX}_{2}$ null mice $(n=34)$ and by $59.3 \pm 8.3$ in slices from $\mathrm{OX}_{1}^{-/-}$mice $(n=25)$. Thus, $\mathrm{Ca}^{2+}$ transients evoked by activation of either orexin receptor involves PKC signaling.

\section{OREXIN ACTIONS IN THE LDT, DR, AND LC REQUIRE THE TWO KNOWN} OREXIN RECEPTORS

Interpretation of our data from single receptor knockouts presupposes that there are only two orexin receptors responsible for orexin actions and that our test concentration of orexin-A is specific for these receptors. We directly tested this by examining the action of orexin- $\mathrm{A}$ on slices made from mice lacking both orexin receptors. As can be seen in Figure 10A, orexinA $(300 \mathrm{nM})$ did not evoke $\mathrm{Ca}^{2+}$ transients in slices from DKO mice. To verify that each of the cells recorded under these conditions remained viable, we followed orexin application with a bolus application of glutamate $(5 \mathrm{mM})$, which rapidly and effectively evoked $\mathrm{Ca}^{2+}$ transients in these same cells (Figure 10B). We also examined extracellular recordings using cell-attached patch recordings, whole-cell currents and the ability of orexin to augment the $\mathrm{Ca}^{2+}$ transients produced by step depolarizations to $-30 \mathrm{mV}$. In each of these tests, orexin-A failed to produce a response. Collectively these data strongly indicate that $300 \mathrm{nM}$ orexin-A is specific for native orexin receptors and that $\mathrm{OX}_{1}$ and $\mathrm{OX}_{2}$ are the only functional orexin receptors expressed in the LDT, DR and LC.

\section{WHOLE BRAINSTEM OX ${ }_{2}$ mRNA LEVELS ARE HIGHER IN MICE LACKING OX}

A potential complication to the interpretation of data from constitutive knockouts is the possibility that the loss of one receptor alters the expression of the other. Indeed, like any lesion study, knockouts can't reveal the function of the missing component but can only reveal the capacity remaining in the absence of that component. We therefore compared $\mathrm{OX}_{1}$ and $\mathrm{OX}_{2}$ mRNA levels isolated from whole brainstems of C57BL6 and receptor knockout mice using quantitative RT-PCR to (Figure 11). Since two splice variants of the $\mathrm{OX}_{2}$ were identified in mice (Chen and Randeva, 2004; Chen et al., 2006), we designed primers for $\mathrm{OX}_{1}$ and both $\mathrm{OX}_{2}$ receptors. The primers used for each receptor were specific since PCR produced single amplicons of the predicted sizes. These amplicons were undetectable in samples from the corresponding single receptor knockout or double receptor knockouts (Figure 11, see gel insets). Results from ANOVAs comparing target mRNA levels by genotype were highly significant for each transcript $(P<0.001)$. Post-hoc testing revealed that the fraction of $\mathrm{OX}_{1}$ mRNA per total mRNA in brainstems from C57BL6 mice $(9.75 \mathrm{E}-6 \pm 2.00 \mathrm{E}-6, n=28$ samples from 14 mice) was not different from that measured from $\mathrm{OX}_{2}^{-1-}$ brainstems (1.07E- $5 \pm$ $1.39 \mathrm{E}-6, n=28$ samples from 14 mice; $P=0.62$; Figure 11A). In contrast, we found that in $\mathrm{OX}_{1}^{-/-}$mice, levels of both the $\mathrm{OX}_{2} \alpha$ $\left(9.48 \mathrm{E}-5 \pm 2.52 \mathrm{E}-5, n=20\right.$ samples from 10 mice) and $\mathrm{OX}_{2} \beta$ $(1.88 \mathrm{E}-4 \pm 3.97 \mathrm{E}-5, n=26$ samples from 13 mice) splice variants were significantly higher compared to those from C57BL6 mice $\left(\mathrm{OX}_{2} \alpha: 7.16 \mathrm{E}-6 \pm 2.27 \mathrm{E}-6, n=14\right.$ samples from 7 mice, $P<0.0001 ; \mathrm{OX}_{2} \beta: 1.94 \mathrm{E}-5 \pm 3.78 \mathrm{E}-6, n=14$ samples from 7 mice, $P<0.0005$; Figures 11B,C).

Since these differences could indicate upregulation of $\mathrm{OX}_{2}$ expression resulting from the absence of $\mathrm{OX}_{1}$ and since the single receptor knockouts were on a mixed C57BL6 and 129SvEv background, we also measured receptor levels in $129 \mathrm{SvEv}$ mice. This comparison indicated that levels of $\mathrm{OX}_{1}$ are higher in 


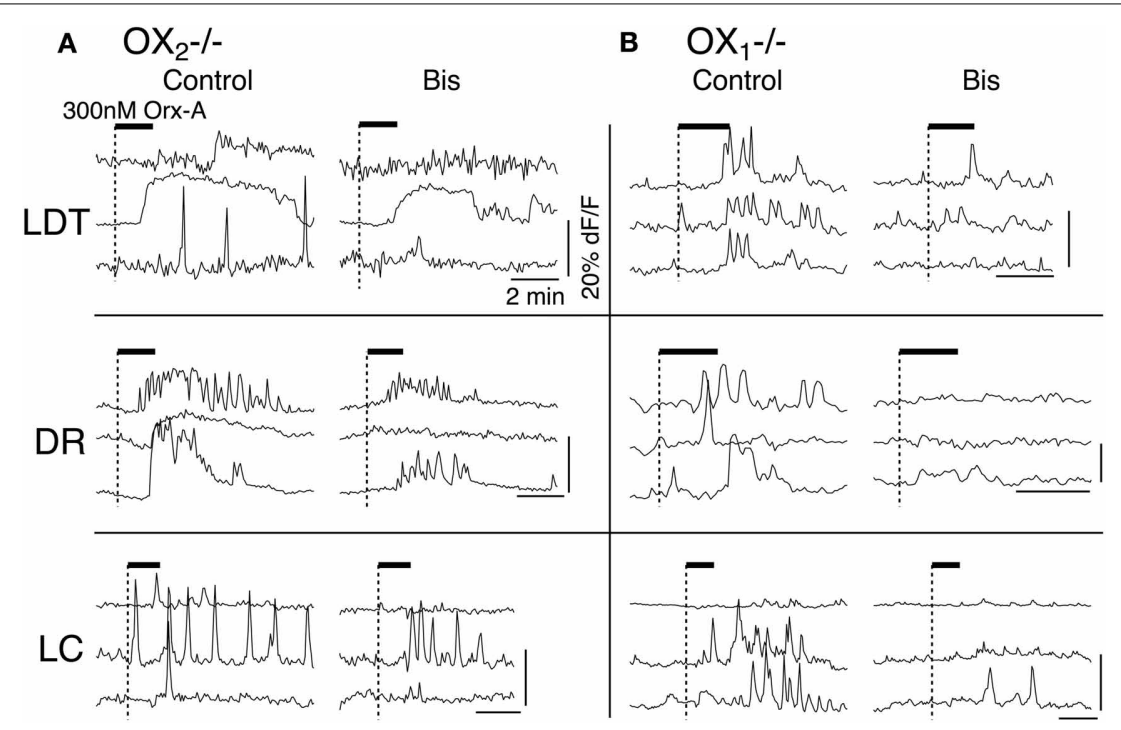

FIGURE 9 | Inhibition of PKC by Bis I attenuated $\mathrm{Ca}^{2+}$-transients evoked by activation $\mathbf{O X}_{\mathbf{1}}$ or $\mathbf{O X}_{\mathbf{2}}$. (A) $\mathrm{Ca}^{2+}$ transients in LDT, DR, and $\mathrm{LC}$ neurons in slices from $\mathrm{OX}_{2}^{-1-}$ mice were attenuated by prior application of Bis I. (B) Similarly, $\mathrm{Ca}^{2+}$ transients in LDT, DR, and LC neurons in slices from $\mathrm{OX}_{1}^{-1-}$ mice were attenuated by prior application of Bis I. Horizontal bars above the traces indicate application of orexin-A $(300 \mathrm{nM})$. Calibration bars indicate $20 \% \mathrm{dF} / \mathrm{F}$ and $2 \mathrm{~min}$ in each panel.
129SvEv brainstems than in either C57BL6 or $\mathrm{OX}_{2}^{-/-}$brainstems (2.89E-5 $\pm 2.04-06, n=16$ samples from 8 mice, $P<0.0001$ for both; Figure 9A). Interestingly, levels of $\mathrm{OX}_{2} \alpha$ (4.08E-5 \pm $1.46 \mathrm{E}-5, n=16$ samples from 8 mice) and $\mathrm{OX}_{2} \beta(7.21 \mathrm{E}-5 \pm$ 3.22E-5, $n=15$ samples from 8 mice) from $129 \mathrm{SvEv}$ brainstems were not statistically different from those in C57BL6 brainstems $\left(\mathrm{OX}_{2} \alpha: P=0.18 ; \mathrm{OX}_{2} \beta: P=0.17\right)$ but were significantly lower than those from $\mathrm{OX}_{1}^{-/-}$brainstems $\left(\mathrm{OX}_{2} \alpha: P<0.02\right.$; $\mathrm{OX}_{2} \beta: P<$ 0.02 ; Figures $11 B, C)$. These findings suggest that background alone is not the reason that $\mathrm{OX}_{2}$ mRNA levels are higher in brainstems from $\mathrm{OX}_{1}^{-/-}$mice and therefore imply some level of compensation.

\section{DISCUSSION}

A major finding of this study is that $\mathrm{OX}_{1}$ exclusively mediates direct depolarization of nNOS+ LDT and TH+ LC neurons, while both receptors mediate direct depolarization of $\mathrm{TpH}+\mathrm{DR}$ neurons. In contrast, augmentation of depolarization-induced $\mathrm{Ca}^{2+}$ transients was mediated by $\mathrm{OX}_{1}$ and $\mathrm{OX}_{2}$ in each nucleus and likely involved L-type $\mathrm{Ca}^{2+}$ channels and PKC signaling. Finally, we found whole-brainstem $\mathrm{OX}_{2}$ mRNA levels were elevated in $\mathrm{OX}_{1}^{-/-}$mice. These findings have implications for understanding the cellular function of native orexin receptors, for understanding the roles played by orexin signaling at these loci in the control of behavioral state and for understanding the consequences of using receptor specific antagonists as therapeutics.

Interpretation of our results are predicated on the idea that the different observed actions of orexin in $\mathrm{OX}_{1}$ null and $\mathrm{OX}_{2}$ null slices result from the absence of orexin receptors rather than from differences in genetic background between each mouse. Since genetic drift occurs and there is allelic variation in each parent strain, possibly in modifier genes, there is some uncertainty to this interpretation (Doetschman, 2009). We found that orexin currents had the same variation of responses and mean amplitude in both C57BL6 mice and in OxrWT, which have the same mixed genetic background as our knockout mice. In both strains, slices from each mouse showed responses to orexin and neither strain showed symptoms of narcolepsy (Kalogiannis et al., 2011) indicating that despite genetic drift and the allelic variations present, orexin signaling at our targets was equivalent in both backgrounds. Moreover, in DKO mice there were no response in any of the cells recorded in any mouse tested, and these mice show severe signs of narcolepsy (Kalogiannis et al., 2011). These considerations, and the recent evidence that the distribution of orexin receptor mRNA is not altered in LDT, DR, or LC in orexin receptor knockouts (Mieda et al., 2011) suggest it is unlikely that the absence of orexin responses result from background effects rather than the loss of the receptor. We therefore interpret our data in terms of receptor loss, mindful of the possibility that responses might also be modulated by background effects.

\section{BOTH NATIVE OREXIN RECEPTORS CAN COUPLE TO A NOISY CATION CURRENT AND L-TYPE $\mathrm{Ca}^{2+}$ CHANNELS}

Recordings from DR neurons in slices from mice lacking either $\mathrm{OX}_{2}$ or $\mathrm{OX}_{1}$ revealed that activation of either receptor evoked a noisy inward current appearing identical to the cation current evoked in wild-type slices (Brown et al., 2002; Liu et al., 2002; Kohlmeier et al., 2008). Since orexin-A did not activate this current in slices lacking both receptors, we conclude that signaling by either receptor converges onto this current and that there are no additional orexin-binding receptors sufficient to mediate this action. The ability of both receptors to augment depolarization-induced $\mathrm{Ca}^{2+}$ transients mediated by L-type $\mathrm{Ca}^{2+}$ channels via a PKC-sensitive pathway further supports 


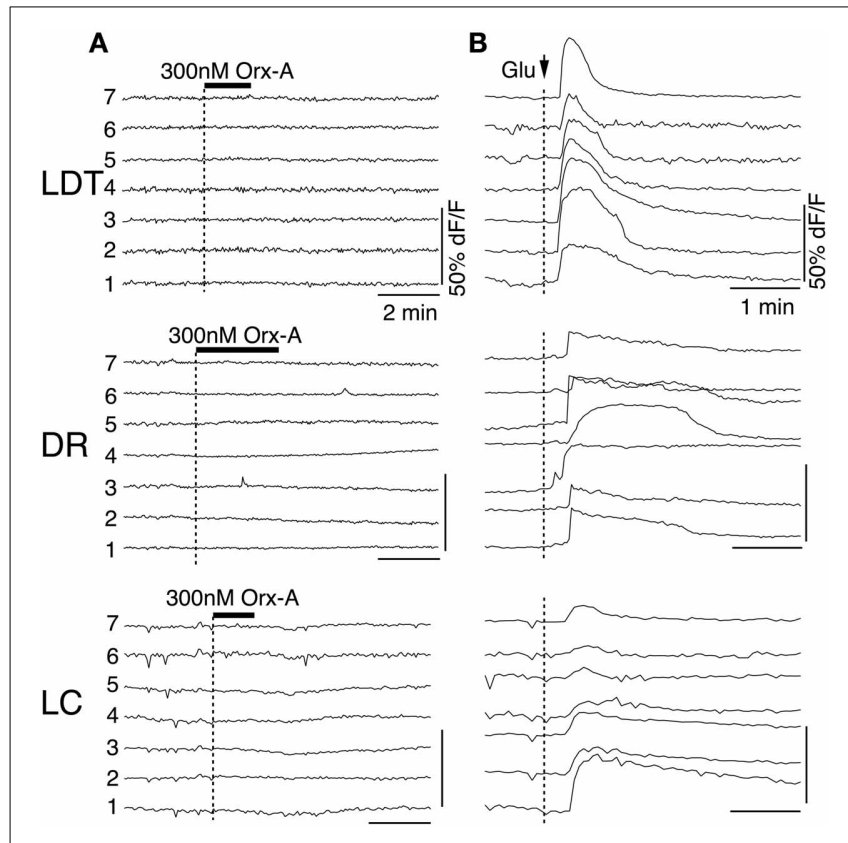

FIGURE 10 | Orexin fails to produce $\mathrm{Ca}^{2+}$ transients in slices from DKO mice. (A) Somatic $\mathrm{dF} / \mathrm{F}$ signals recorded from fura-2AM loaded LDT, DR, and LC cells in slices from DKO mice. Orexin-A application did not produce detectable changes in $\mathrm{dF} / \mathrm{F}$ for any recorded cell. (B) Bolus application of glutamate $\left(5 \mathrm{mM}\right.$; delivered at arrow) produced strong $\mathrm{Ca}^{2+}$ transients in the same cells indicating that they remained viable. Horizontal bars above the traces indicate application of orexin-A (Orx-A; $300 \mathrm{nM})$. Calibration bars indicate $50 \% \mathrm{dF} / \mathrm{F}$ and $2 \mathrm{~min}$ in (A) and $50 \% \mathrm{dF} / \mathrm{F}$ and $1 \mathrm{~min}$ in (B)

convergent or redundant functions of native $\mathrm{OX}_{1}$ and $\mathrm{OX}_{2}$ in DR neurons. Immunofluorescence identification demonstrated that this convergence includes serotonergic DR neurons $(\mathrm{TpH}+)$. These findings fit well with double in-situ hybridization evidence indicating both receptors are co-localized within a large fraction of TpH-expressing neurons in mouse DR (Mieda et al., 2011), and with single-cell RT-PCR evidence indicating both $\mathrm{OX}_{1}$ and $\mathrm{OX}_{2}$ mRNA is typically recovered from $\mathrm{TpH}$ neurons in rat (Brown et al., 2002). Together, these data suggest that both orexin receptors normally excite $\mathrm{TpH}$ neurons and augment their intracellular $\mathrm{Ca}^{2+}$-levels during periods of prolonged depolarization.

Since the average $\mathrm{OX}_{1}$-evoked inward current was somewhat larger than the $\mathrm{OX}_{2}$-evoked current, and since $\mathrm{OX}_{1}$ activation produced $\mathrm{Ca}^{2+}$ transients in a greater fraction of DR neurons than did $\mathrm{OX}_{2}$ activation, it is plausible that $\mathrm{OX}_{1}$ normally mediates the larger part of the orexin-mediated depolarization of DR neurons. A previous pharmacological study of rat DR slices concluded that $\mathrm{OX}_{2}$ is primarily responsible for orexin-evoked spiking (Soffin et al., 2004). However, that conclusion was based on data that was acknowledged to be difficult to interpret and suffered from limitations related to the use of selective agonists for receptor subtype identification (see also Leonard and Kukkonen, 2013). Co-expression and convergent action of these receptors also likely contributed to interpretive difficulties (e.g., the relatively weak effect of the $\mathrm{OX}_{1}$-selective antagonist SB 334867). Use of conditional receptor knockouts and development of subtype-specific receptor antagonists should help to further clarify the natural role of each receptor.

In contrast to the $\mathrm{DR}, \mathrm{OX}_{1}$ was necessary for orexin to elicit depolarizing currents in principal LDT and LC neurons, which fits well with the high levels of $\mathrm{OX}_{1}$ mRNA in these structures from adult rodents (Marcus et al., 2001; Mieda et al., 2011). Since $\mathrm{OX}_{2}$ is competent to activate a similar depolarizing current in DR neurons, it is possible that $\mathrm{OX}_{2}$ is either not expressed, or is incapable of activating available depolarizing channels in LDT and LC neurons. Isotopic in-situ hybridization indicates $\mathrm{OX}_{2}$ message is much less abundant than $\mathrm{OX}_{1}$ but is above background in both the LDT and LC (Marcus et al., 2001), suggesting that low levels of $\mathrm{OX}_{2}$ are present. Recent double, non-isotopic, in-situ hybridization studies detected $\mathrm{OX}_{2}$ only in non-cholinergic LDT neurons and non-TH+ LC neurons (Mieda et al., 2011). Nevertheless, we found clear examples of LDT and LC neurons where orexinA enhanced depolarization-induced $\mathrm{Ca}^{2+}$ transients in $\mathrm{OX}_{1}$ null slices, albeit fewer LDT and LC neurons were activated compared to slices from wild-type or $\mathrm{OX}_{2}$ null mice (Figure 8). Moreover, we recovered nNOS+ and $\mathrm{TH}+$ neurons showing orexin-augmented $\mathrm{Ca}^{2+}$-transients, indicating that $\mathrm{OX}_{2}$ signaling influences at least a sub-population of these neurons (Figure 6). These latter findings are consistent with the possibility that $\mathrm{OX}_{2}$ expression in LDT and LC neurons might be developmentally regulated and could be lower in adult mice compared to the 2-4 week-old-mice used here, or simply that functional $\mathrm{OX}_{2}$ receptors are present, but that mRNA levels are too low to be detected with double in-situ hybridization methods, which are generally less sensitive than isotopic methods. If this is the case, how then does $\mathrm{OX}_{2}$ augment the depolarization-induced $\mathrm{Ca}^{2+}$ influx without also producing a depolarization? One possibility is that there is spatial segregation of $\mathrm{OX}_{1}$ and $\mathrm{OX}_{2}$ and their respective effectors such that $\mathrm{OX}_{2}$ signaling can't activate the depolarization channels. Another possibility is that each receptor activates different second messenger cascades and the depolarizing channels in LDT and LC are only activated by the cascade(s) from $\mathrm{OX}_{1}$. Neither scenario has been demonstrated for native orexin receptors and both deserve further investigation. In general, the messenger cascades underlying native orexin receptor actions are poorly understood, although they appear more diverse that originally thought (for review see Kukkonen and Leonard, 2013). Moreover, the cascades mediating depolarization in these neurons have not been identified, although since PKC is involved with augmenting $\mathrm{Ca}^{2+}$. transients, both receptors may activate PLC, as has been often found elsewhere (for review see Kukkonen and Leonard, 2013). While the cation currents activated in LDT and DR appear quite similar, we did find previously that low- $\mathrm{Ca}^{2+}$ ACSF augments the DR current, but not the LDT current (Kohlmeier et al., 2008), suggesting the possibility that different channels may mediate the orexin-activated cation current in these neurons. Future experiments are needed to clarify the signaling pathways and effectors utilized by each receptor in these neurons.

Finally, it is also possible that the orexin-enhanced $\mathrm{Ca}^{2+}$ transients were produced indirectly by an unknown mediator released from $\mathrm{OX}_{2}$-expressing nNOS- and $\mathrm{TH}-$ neurons in response to orexin-A. This seems unlikely since blocking action potentials with TTX, did not attenuate the orexin effects. However, this is 


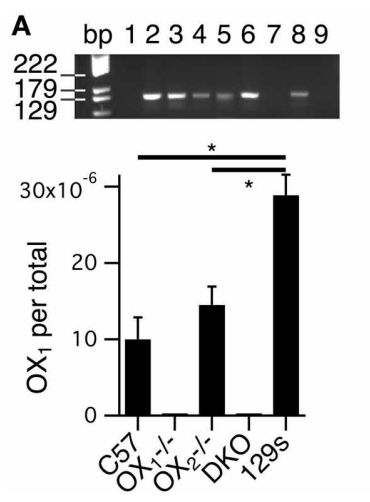

B
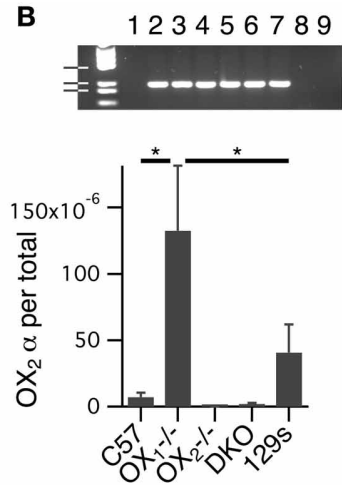

C
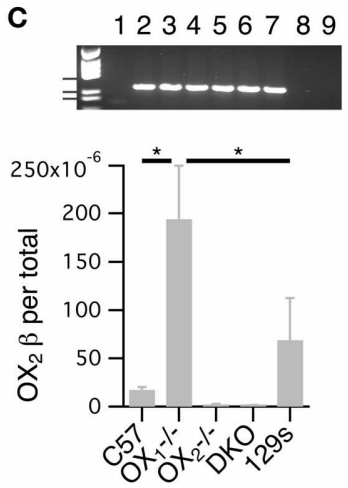

FIGURE 11 | Levels of whole brainstem OX ${ }_{2}$ mRNA are higher in $\mathrm{OX}_{\mathbf{1}}^{-/-}$mice compared to wild-type mice. (A-C) Top Gel images of the amplicons resulting from probes for $\mathrm{OX}_{1}$ (A), $\mathrm{OX}_{2} \alpha$ (B), and $\mathrm{OX}_{2} \beta$ (C). Samples for each lane were 1: blank, 2-5: scales for corresponding receptor, 6: C57 sample, 7: $\mathrm{OX}_{1}^{-1-}$ sample, 8: $\mathrm{OX}_{2}^{-1-}$ sample, 9: DKO sample. (A) Bottom RNA for $\mathrm{OX}_{1}\left(\mathrm{OX}_{1}\right.$ per total) was quantified from whole brainstems of C57BL6(C57; 28 samples from 14 mice), OXX 19 samples from 5 mice), $\mathrm{OX}_{2}^{-/-}(28$ samples from 14 mice), double orexin receptor knockouts (DKO; 8 samples from 4 mice) and 129SvEv (129s; 16 samples from 8 mice) mice by RT-PCR. OX 1 mRNA was undetectable in tissue from $\mathrm{OX}_{1-/-}$ and DKO mice. Despite significantly higher levels of $\mathrm{OX}_{1}$ mRNA in brainstems from 129s mice compared to C57 and $\mathrm{OX}_{2}^{-1-}$ brainstems $(* P<0.0001)$, there was no significant difference between
mRNA levels measured in brainstems from $\mathrm{C} 57$ and $\mathrm{OX}_{2}^{-1-}$ mice. (B) Bottom mRNA levels for $\mathrm{OX}_{2} \alpha\left(\mathrm{OX}_{2} \alpha\right.$ per total) were measured from isolates obtained from the same mice used in (A). $\mathrm{OX}_{2} \alpha$ mRNA was undetectable in tissue from $\mathrm{OX}_{2}^{-1-}(7$ samples from 4 mice) and DKOs (20 samples from 10 mice). OX $2 \alpha$ mRNA levels were higher in $\mathrm{OX}_{1}^{-/-}$samples (20 samples from 10 mice) than in either C57 (14 samples from 7 mice) or 129s (16 samples from 8 mice) samples $(* P<0.02)$. (C) Bottom Similarly, mRNA levels for $\mathrm{OX}_{2} \beta$ $\left(\mathrm{OX}_{2} \beta\right.$ per total) were measured from mRNA isolates from the same mice in $\mathrm{A} . \mathrm{OX}_{2} \beta$ mRNA was undetectable in tissue from $\mathrm{OX}_{2}^{-/-}(14$ samples from 7 mice) and DKOs (20 samples from 10 mice). $\mathrm{OX}_{2} \beta$ mRNA levels were higher in tissue from $\mathrm{OX}_{1}^{-1-}$ mice $(26$ samples from 13 mice) than in tissue from either C57 (14 samples from 7 mice) or $129 \mathrm{~s}$ mice (15 samples from 8 mice, $* P<0.02$ ). difficult to rule out since conventional procedures to block $\mathrm{Ca}^{2+}$ dependent release, like lowering extracellular $\mathrm{Ca}^{2+}$ or adding $\mathrm{Co}^{2+}$ or $\mathrm{Cd}^{2+}$, also block the $\mathrm{Ca}^{2+}$ influx we monitored. Future studies using acutely isolated neurons could help address this issue.

\section{ROLES OF OREXIN SIGNALING IN RETICULAR ACTIVATING SYSTEM NEURONS}

Our main finding demonstrates that $\mathrm{OX}_{1}$ is required for orexinmediated excitation of LC and LDT neurons but that either receptor is sufficient to mediate excitation of DR neurons. While subtle developmental changes in orexin receptor distribution cannot be ruled out, this main finding, obtained from young mice, agrees very well with orexin receptor mRNA levels in these neurons from adult mice (Mieda et al., 2011). It is therefore possible to compare the impairment of excitation observed here to the degree of behavioral impairment reported for each knockout, in order to gain insight into the functional consequences of orexin receptor signaling at these loci. Deletion of both receptors produces a narcolepsy phenotype (Hondo et al., 2010; Kalogiannis et al., 2011) similar to that seen in the prepro-orexin knockouts (Chemelli et al., 1999; Mochizuki et al., 2004), with fragmented waking states, spontaneous sleep attacks and frequent cataplexy. Since orexin-A normally stimulates a large fraction of LDT, DR, and LC neurons, the loss of orexin action at these sites in the DKOs is consistent with a role for orexin signaling at these loci in promoting wake and sleep consolidation, suppressing REM sleep, preventing sleep attacks and suppressing cataplexy. Indeed, optogenetic excitation of orexin neurons promotes sleep-to-wake transitions (Adamantidis et al., 2007) and optogenetic inhibition of orexin neurons promotes slow-wave sleep and reduced firing of DR neurons (Tsunematsu et al., 2011), while focal orexin injection into the LDT (Xi et al., 2001) or LC (Bourgin et al., 2000) prolongs waking bouts and suppresses REM sleep. Moreover, optogenetic inhibition of TH+ LC neurons blocks the ability of orexin neuron stimulation to promote sleep-to-wake transitions (Carter et al., 2012), while ontogenetic stimulation of $\mathrm{TH}+$ LC neurons both prolongs waking (Carter et al., 2010) and enhances the wake-promoting effect of orexin neuron stimulation (Carter et al., 2012). This indicates orexin-excitation of TH+ LC neurons is necessary for orexin neuron activity to promote sleep-to-wake transitions. Nevertheless, it is the $\mathrm{OX}_{2}$ knockouts that show fragmented spontaneous waking and sleep states and have sleep attacks at the same frequency as prepro-orexin knockouts (Willie et al., 2003), even though orexin-mediated excitation of LDT, DR, and LC neurons is preserved (Figure 2). This might indicate that orexin neuron firing and orexin release is impaired through the loss of $\mathrm{OX}_{2}$-mediated positive feedback (Yamanaka et al., 2010) and/or that residual OX $_{1}$-excitation of LDT, DR, and LC neurons is insufficient to maintain normal duration bouts of spontaneous waking and sleep in the absence of $\mathrm{OX}_{2}$, even though ICV orexin still prolongs waking and suppresses REM sleep in $\mathrm{OX}_{2}^{-1-}$ mice (Mieda et al., 2011). Conversely, $\mathrm{OX}_{1}^{-/-}$ mice appear to have normal sleep-wake states without fragmentation or sleep attacks (Hondo et al., 2010; Mieda et al., 2011), even though orexin excitation is abolished in LDT and LC neurons and is reduced in DR neurons (Figure 5), in spite of possible upregulation of $\mathrm{OX}_{2}$ (Figure 11). Thus, it appears intact orexin 
excitation in the LDT, DR, and LC is neither necessary nor sufficient for the expression of normally consolidated bouts of spontaneous sleep and waking. Since, $\mathrm{OX}_{1}$ signaling in LDT, $\mathrm{DR}$, and LC promotes arousal, but is not necessary for consolidated spontaneous waking, orexin signaling at these loci may promote context-dependent arousal associated with, for example, stress, anxiety, panic, and/or food and drug seeking behavior (Winskey-Sommerer et al., 2004; Boutrel et al., 2005; Harris et al., 2005; Nair et al., 2008; Johnson et al., 2012; Piccoli et al., 2012; Steiner et al., 2012; Heydendael et al., 2013). Orexin signaling at these loci may also support other functions. For example, $\mathrm{OX}_{1}^{-/-}$mice show impaired acquisition and expression of cued and contextual fear conditioning and the re-expression of $\mathrm{OX}_{1}$ in $\mathrm{TH}+\mathrm{LC}$ neurons rescues the expression of cued fear (Soya et al., 2013). Future studies using receptor rescue approaches (Mochizuki et al., 2011) or the local application of $\mathrm{OX}_{1}$-specific antagonists will be needed to further explore $\mathrm{OX}_{1}$ functions at these loci.

Our findings are also consistent with a cataplexy-suppressing role for orexin excitation in the LDT, DR and LC. $\mathrm{OX}_{2}^{-/-}$mice have cataplexy but it occurs rarely compared with prepro-orexin null mice (Willie et al., 2003). Since DKO mice show frequent cataplexy-like arrests (Kalogiannis et al., 2011), the less severe cataplexy in $\mathrm{OX}_{2}^{-/-}$mice is likely related to residual $\mathrm{OX}_{1}$ signaling. Since orexin injections into the LDT and LC suppress REM sleep, and knockdown of $\mathrm{OX}_{1}$ in LC increases REM during the dark phase (Chen et al., 2010) it is plausible that remaining $\mathrm{OX}_{1}$-excitation in LDT, LC, and perhaps DR, reduces cataplexy in $\mathrm{OX}_{2}^{-/-}$mice. Nevertheless, $\mathrm{OX}_{1}^{-/-}$mice do not have cataplexy, indicating that the loss of orexin-excitation in LDT and LC and reduced orexin excitation in the DR is not sufficient to produce cataplexy, at least in these knockouts, where $\mathrm{OX}_{2}$ may also be up regulated.

\section{IMPLICATIONS FOR SINGLE OREXIN RECEPTOR PHARMACOTHERAPEUTICS}

DORAs show significant promise for improved treatment of insomnia (Uslaner et al., 2013; Winrow and Renger, 2013) and are currently being considered for FDA approval. Given that orexins regulate numerous functions beyond normal waking and sleep and that their receptors are differentially distributed, it seems likely that subtype-specific orexin receptor antagonists (SORAs) will have even greater therapeutic potential. The development of sub-type specific drugs will accelerate preclinical investigations of receptor function and, may allow better targeting of different orexin-dependent behaviors and a fine-tuning of their sleep-promoting effects. For example, $\mathrm{OX}_{2}$ antagonists appear more effective at sleep promotion than DORAs (Dugovic et al., 2009), perhaps by targeting hypothalamic circuits promoting histamine release and consolidated waking (Dugovic et al., 2009; Mochizuki et al., 2011). Conversely, $\mathrm{OX}_{1}$ antagonists may provide better relief for hyperarousal and other maladaptive behaviors associated with stress, as noted above, perhaps by dampening $\mathrm{OX}_{1}$ excitation of noradrenergic, serotonergic and cholinergic reticular neurons and midbrain dopamine systems. Nevertheless, much more needs to be learned about how each orexin receptor impacts their cellular targets and how these targets influence behavior. These interactions are likely to be complex: as demonstrated here for key elements of the reticular activating system, each receptor can have common effectors (i.e., both receptors activating depolarizing channels and enhancing voltage-dependent $\mathrm{Ca}^{2+}$ transients in TpH DR neurons) or act differentially with respect to one effector while having a common action on another effector (i.e., $\mathrm{OX}_{1}$ is necessary for depolarization while both receptors enhance voltage-dependent $\mathrm{Ca}^{2+}$ transients in LDT and LC neurons). It will also be important in future experiments to evaluate the degree to which persistent alteration of signaling by either orexin receptor impacts synaptic plasticity (Borgland et al., 2006; Selbach et al., 2010), neurotransmitter phenotypes (Kalogiannis et al., 2010; Valko et al., 2013) and orexin receptor expression (i.e., elevated brainstem $\mathrm{OX}_{2}$ message levels in $\mathrm{OX}_{1}$ null mice), as each of these could lead to deleterious side-effects and diminished therapeutic potential.

\section{ACKNOWLEDGMENTS}

Research was supported by NIH grants NS27881 and HL64150

\section{REFERENCES}

Adamantidis, A. R., Zhang, F., Aravanis, A. M., Deisseroth, K., and De Lecea, L. (2007). Neural substrates of awakening probed with optogenetic control of hypocretin neurons. Nature 450, 420-424. doi: 10.1038/ nature 06310

Bayer, L., Eggermann, E., Saint-Mleux, B., Machard, D., Jones, B. E., Muhlethaler, M., et al. (2002). Selective action of orexin (hypocretin) on nonspecific thalamocortical projection neurons. J. Neurosci. 22, 7835-7839.

Beuckmann, C. T., Sinton, C. M., Williams, S. C., Richardson, J. A., Hammer, R. E., Sakurai, T., et al. (2004). Expression of a poly-glutamine-ataxin-3 transgene in orexin neurons induces narcolepsy-cataplexy in the rat. J. Neurosci. 24, 4469-4477. doi: 10.1523/JNEUROSCI.5560-03.2004

Bisetti, A., Cvetkovic, V., Serafin, M., Bayer, L., Machard, D., Jones, B. E., et al. (2006). Excitatory action of hypocretin/orexin on neurons of the central medial amygdala. Neuroscience 142, 999-1004. doi: 10.1016/j.neuroscience. 2006.07.018

Borgland, S. L., Taha, S. A., Sarti, F., Fields, H. L., and Bonci, A. (2006). Orexin A in the VTA is critical for the induction of synaptic plasticity and behavioral sensitization to cocaine. Neuron 49, 589-601. doi: 10.1016/j.neuron. 2006.01.016

Bourgin, P., Huitron-Resendiz, S., Spier, A. D., Fabre, V., Morte, B., Criado, J. R., et al. (2000). Hypocretin-1 modulates rapid eye movement sleep through activation of locus coeruleus neurons. J. Neurosci. 20, 7760-7765.

Boutrel, B., Kenny, P. J., Specio, S. E., Martin-Fardon, R., Markou, A., Koob, G. F., et al. (2005). Role for hypocretin in mediating stress-induced reinstatement of cocaine-seeking behavior. Proc. Natl. Acad. Sci. U.S.A. 102, 19168-19173. doi: 10.1073/pnas.0507480102

Brown, R. E., Basheer, R., McKenna, J. T., Strecker, R. E., and McCarley, R. W. (2012). Control of sleep and wakefulness. Physiol. Rev. 92, 1087-1187. doi: 10.1152/physrev.00032.2011

Brown, R. E., Sergeeva, O. A., Eriksson, K. S., and Haas, H. L. (2002). Convergent excitation of dorsal raphe serotonin neurons by multiple arousal systems (orexin/hypocretin, histamine and noradrenaline). J. Neurosci. 22, 8850-8859.

Burdakov, D., Liss, B., and Ashcroft, F. M. (2003). Orexin excites GABAergic neurons of the arcuate nucleus by activating the sodium-calcium exchanger. J. Neurosci. 23, 4951-4957.

Burlet, S., Tyler, C. J., and Leonard, C. S. (2002). Direct and indirect excitation of laterodorsal tegmental neurons by hypocretin/orexin peptides: implications for wakefulness and narcolepsy. J. Neurosci. 22, 2862-2872.

Carter, M. E., Brill, J., Bonnavion, P., Huguenard, J. R., Huerta, R., and De Lecea, L. (2012). Mechanism for Hypocretin-mediated sleep-to-wake transitions. Proc. Natl. Acad. Sci. U.S.A. 109, E2635-E2644. doi: 10.1073/pnas.1202526109 
Carter, M. E., Yizhar, O., Chikahisa, S., Nguyen, H., Adamantidis, A., Nishino, S., et al. (2010). Tuning arousal with optogenetic modulation of locus coeruleus neurons. Nat. Neurosci. 13, 1526-1533. doi: 10.1038/nn.2682

Chemelli, R. M., Willie, J. T., Sinton, C. M., Elmquist, J. K., Scammell, T., Lee, C., et al. (1999). Narcolepsy in orexin knockout mice: molecular genetics of sleep regulation. Cell 98, 437-451. doi: 10.1016/S0092-8674(00)81973-X

Chen, J., Karteris, E., Collins, D., and Randeva, H. S. (2006). Differential expression of mouse orexin receptor type-2 (OX2R) variants in the mouse brain. Brain Res. 1103, 20-24. doi: 10.1016/j.brainres.2006.05.054

Chen, J., and Randeva, H. S. (2004). Genomic organization of mouse orexin receptors: characterization of two novel tissue-specific splice variants. Mol. Endocrinol. 18, 2790-2804. doi: 10.1210/me.2004-0167

Chen, L., McKenna, J. T., Bolortuya, Y., Winston, S., Thakkar, M. M., Basheer, R., et al. (2010). Knockdown of orexin type 1 receptor in rat locus coeruleus increases REM sleep during the dark period. Eur. J. Neurosci. 32, 1528-1536. doi: 10.1111/j.1460-9568.2010.07401.x

Cid-Pellitero, E. D., and Garzón, M. (2011). Hypocretin1/orexina axon targeting of laterodorsal tegmental nucleus neurons projecting to the rat medial prefrontal cortex. Cereb. Cortex 21, 2762-2773. doi: 10.1093/cercor/bhr070

Del Cid-Pellitero, E., and Garzón, M. (2011). Medial prefrontal cortex receives input from dorsal raphe nucleus neurons targeted by hypocretin1/orexinA-containing axons. Neuroscience 172, 30-43. doi: 10.1016/j.neuroscience.2010.10.058

De Lecea, L., Kilduff, T. S., Peyron, C., Gao, X., Foye, P. E., Danielson, P. E., et al. (1998). The hypocretins: hypothalamus-specific peptides with neuroexcitatory activity. Proc. Natl. Acad. Sci. U.S.A. 95, 322-327. doi: 10.1073/pnas. 95.1.322

Doetschman, T. (2009). Influence of genetic background on genetically engineered mouse phenotypes. Methods Mol. Biol. 530, 423-433. doi: 10.1007/978-1-59745471-1_23

Dugovic, C., Shelton, J. E., Aluisio, L. E., Fraser, I. C., Jiang, X., Sutton, S. W., et al. (2009). Blockade of orexin-1 receptors attenuates orexin-2 receptor antagonism-induced sleep promotion in the rat. J. Pharmacol. Exp. Ther. 330, 142-151. doi: 10.1124/jpet.109.152009

Eriksson, K. S., Sergeeva, O., Brown, R. E., and Haas, H. L. (2001). Orexin/hypocretin excites the histaminergic neurons of the tuberomammillary nucleus. J. Neurosci. 21, 9273-9279.

Grabauskas, G., and Moises, H. C. (2003). Gastrointestinal-projecting neurones in the dorsal motor nucleus of the vagus exhibit direct and viscerotopically organized sensitivity to orexin. J. Physiol. 549, 37-56. doi: 10.1113/jphysiol.2002.029546

Haj-Dahmane, S., and Shen, R. Y. (2005). The wake-promoting peptide orexin-B inhibits glutamatergic transmission to dorsal raphe nucleus serotonin neurons through retrograde endocannabinoid signaling. J. Neurosci. 25, 896-905. doi: 10.1523/JNEUROSCI.3258-04.2005

Hara, J., Beuckmann, C. T., Nambu, T., Willie, J. T., Chemelli, R. M., Sinton, C. M., et al. (2001). Genetic ablation of orexin neurons in mice results in narcolepsy, hypophagia, and obesity. Neuron 30, 345-354. doi: 10.1016/S08966273(01)00293-8

Harris, G. C., Wimmer, M., and Aston-Jones, G. (2005). A role for lateral hypothalamic orexin neurons in reward seeking. Nature 437, 556-559. doi: 10.1038/nature04071

Hervieu, G. J., Cluderay, J. E., Harrison, D. C., Roberts, J. C., and Leslie, R. A. (2001). Gene expression and protein distribution of the orexin-1 receptor in the rat brain and spinal cord. Neuroscience 103, 777-797. doi: 10.1016/S03064522(01)00033-1

Heydendael, W., Sengupta, A., Beck, S., and Bhatnagar, S. (2013). Optogenetic examination identifies a context-specific role for orexins/hypocretins in anxietyrelated behavior. Physiol. Behav. doi: 10.1016/j.physbeh.2013.10.005. [Epub ahead of print].

Hoang, Q. V., Bajic, D., Yanagisawa, M., Nakajima, S., and Nakajima, Y. (2003). Effects of orexin (hypocretin) on GIRK channels. J. Neurophysiol. 90, 693-702. doi: 10.1152/jn.00001.2003

Hoang, Q. V., Zhao, P., Nakajima, S., and Nakajima, Y. (2004). Orexin (hypocretin) effects on constitutively active inward rectifier $\mathrm{K}+$ channels in cultured nucleus basalis neurons. J. Neurophysiol. 92, 3183-3191. doi: 10.1152/jn.01222.2003

Holmqvist, T., Åkerman, K. E. O., and Kukkonen, J. P. (2002). Orexin signaling in recombinant neuron-like cells. FEBS Lett. 526, 11-14. doi: 10.1016/S00145793(02)03101-0
Hondo, M., Nagai, K., Ohno, K., Kisanuki, Y., Willie, J. T., Watanabe, T., et al. (2010). Histamine-1 receptor is not required as a downstream effector of orexin2 receptor in maintenance of basal sleep/wake states. Acta Physiol. (Oxf.) 198, 287-294. doi: 10.1111/j.1748-1716.2009.02032.x

Horvath, T. L., Peyron, C., Diano, S., Ivanov, A., Aston-Jones, G., Kilduff, T. S., et al. (1999). Hypocretin (orexin) activation and synaptic innervation of the locus coeruleus noradrenergic system. J. Comp. Neurol. 415, 145-159. doi: 10.1002/(SICI)1096-9861(19991213)415:2<145::AID-CNE1>3.0.CO;2-2

Hwang, L. L., Chen, C. T., and Dun, N. J. (2001). Mechanisms of orexin-induced depolarizations in rat dorsal motor nucleus of vagus neurones in vitro. J. Physiol. 537, 511-520. doi: 10.1111/j.1469-7793.2001.00511.x

Ishibashi, M., Takano, S., Yanagida, H., Takatsuna, M., Nakajima, K., Oomura, Y., et al. (2005). Effects of orexins/hypocretins on neuronal activity in the paraventricular nucleus of the thalamus in rats in vitro. Peptides 26, 471-481. doi: 10.1016/j.peptides.2004.10.014

Ivanov, A., and Aston-Jones, G. (2000). Hypocretin/orexin depolarizes and decreases potassium conductance in locus coeruleus neurons. Neuroreport 11, 1755-1758. doi: 10.1097/00001756-200006050-00031

Jacobs, B. L., and Fornal, C. A. (1993). 5-HT and motor control: a hypothesis. Trends Neurosci. 16, 346-352. doi: 10.1016/0166-2236(93)90090-9

Johnson, P. L., Samuels, B. C., Fitz, S. D., Lightman, S. L., Lowry, C. A., and Shekhar, A. (2012). Activation of the orexin 1 receptor is a critical component of CO2-mediated anxiety and hypertension but not bradycardia. Neuropsychopharmacology 37, 1911-1922. doi: 10.1038/npp. 2012.38

Jones, B. E. (2005). From waking to sleeping: neuronal and chemical substrates. Trends Pharmacol. Sci. 26, 578-586. doi: 10.1016/j.tips.2005.09.009

Kalogiannis, M., Grupke, S. L., Potter, P. E., Edwards, J. G., Chemelli, R. M., Kisanuki, Y. Y., et al. (2010). Narcoleptic orexin receptor knockout mice express enhanced cholinergic properties in laterodorsal tegmental neurons. Eur. J. Neurosci. 32, 130-142. doi: 10.1111/j.1460-9568.2010.07259.x

Kalogiannis, M., Hsu, E., Willie, J. T., Chemelli, R. M., Kisanuki, Y. Y., Yanagisawa, M., et al. (2011). Cholinergic modulation of narcoleptic attacks in double orexin receptor knockout mice. PLoS ONE 6:e18697. doi: 10.1371/journal.pone.0018697

Kim, J., Nakajima, K., Oomura, Y., Wayner, M. J., and Sasaki, K. (2009). Electrophysiological effects of orexins/hypocretins on pedunculopontine tegmental neurons in rats: an in vitro study. Peptides 30, 191-209. doi: 10.1016/j.peptides.2008.09.023

Kohlmeier, K. A., Inoue, T., and Leonard, C. S. (2004). Hypocretin/orexin peptide signaling in the ascending arousal system: elevation of intracellular calcium in the mouse dorsal raphe and laterodorsal tegmentum. J. Neurophysiol. 92, 221-235. doi: 10.1152/jn.00076.2004

Kohlmeier, K. A., Watanabe, S., Tyler, C. J., Burlet, S., and Leonard, C. S. (2008). Dual orexin actions on dorsal raphe and laterodorsal tegmentum neurons: noisy cation current activation and selective enhancement of Ca transients mediated by L-type calcium channels. J. Neurophysiol. 100, 2265-2281. doi: 10.1152/jn.01388.2007

Kukkonen, J. P., and Leonard, C. S. (2013). Orexin/hypocretin receptor signalling cascades. Br. J. Pharmacol. doi: 10.1111/bph.12324. [Epub ahead of print].

Leonard, C. S., and Kukkonen, J. P. (2013). Orexin/hypocretin receptor signalling: a functional perspective. Br. J. Pharmacol. doi: 10.1111/bph.12296. [Epub ahead of print].

Li, Y., Gao, X. B., Sakurai, T., and Van Den Pol, A. N. (2002). Hypocretin/Orexin excites hypocretin neurons via a local glutamate neuron-A potential mechanism for orchestrating the hypothalamic arousal system. Neuron 36, 1169-1181. doi: 10.1016/S0896-6273(02)01132-7

Lin, L., Faraco, J., Li, R., Kadotani, H., Rogers, W., Lin, X., et al. (1999). The sleep disorder canine narcolepsy is caused by a mutation in the hypocretin (orexin) receptor 2 gene. Cell 98, 365-376. doi: 10.1016/S0092-8674(00)81965-0

Liu, R. J., Van Den Pol, A. N., and Aghajanian, G. K. (2002). Hypocretins (orexins) regulate serotonin neurons in the dorsal raphe nucleus by excitatory direct and inhibitory indirect actions. J. Neurosci. 22, 9453-9464.

Lowry, C. A., Johnson, P. L., Hay-Schmidt, A., Mikkelsen, J., and Shekhar, A. (2005). Modulation of anxiety circuits by serotonergic systems. Stress 8, 233-246. doi: 10.1080/10253890500492787

Lund, P. E., Shariatmadari, R., Uustare, A., Detheux, M., Parmentier, M., Kukkonen, J. P., and Åkerman, K. E. O. (2000). The orexin OX1 receptor activates a novel $\mathrm{Ca} 2+$ influx pathway necessary for coupling to phospholipase C. J. Biol. Chem. 275, 30806-30812. doi: 10.1074/jbc.M002603200 
Marcus, J. N., Aschkenasi, C. J., Lee, C. E., Chemelli, R. M., Saper, C. B., Yanagisawa, M., et al. (2001). Differential expression of orexin receptors 1 and 2 in the rat brain. J. Comp. Neurol. 435, 6-25. doi: 10.1002/cne.1190

Maskos, U. (2008). The cholinergic mesopontine tegmentum is a relatively neglected nicotinic master modulator of the dopaminergic system: relevance to drugs of abuse and pathology. Br. J. Pharmacol. 153(Suppl. 1), S438-S445. doi: 10.1038/bjp.2008.5

Mena-Segovia, J., Winn, P., and Bolam, J. P. (2008). Cholinergic modulation of midbrain dopaminergic systems. Brain Res. Rev. 58, 265-271. doi: 10.1016/j. brainresrev.2008.02.003

Michelsen, K. A., Schmitz, C., and Steinbusch, H. W. (2007). The dorsal raphe nucleus-from silver stainings to a role in depression. Brain Res. Rev. 55, 329-342. doi: 10.1016/j.brainresrev.2007.01.002

Mieda, M., Hasegawa, E., Kisanuki, Y. Y., Sinton, C. M., Yanagisawa, M., and Sakurai, T. (2011). Differential roles of orexin receptor-1 and -2 in the regulation of non-REM and REM sleep. J. Neurosci. 31, 6518-6526. doi: 10.1523/JNEUROSCI.6506-10.2011

Mochizuki, T., Arrigoni, E., Marcus, J. N., Clark, E. L., Yamamoto, M., Honer, M., et al. (2011). Orexin receptor 2 expression in the posterior hypothalamus rescues sleepiness in narcoleptic mice. Proc. Natl. Acad. Sci. U.S.A. 108, 4471-4476. doi: $10.1073 /$ pnas. 1012456108

Mochizuki, T., Crocker, A., McCormack, S., Yanagisawa, M., Sakurai, T., and Scammell, T. (2004). Behavioral State Instability in Orexin Knockout Mice. J. Neurosci. 24, 6291-6300. doi: 10.1523/JNEUROSCI. 0586-04.2004

Murai, Y., and Akaike, T. (2005). Orexins cause depolarization via nonselective cationic and $\mathrm{K}+$ channels in isolated locus coeruleus neurons. Neurosci. Res. 51, 55-65. doi: 10.1016/j.neures.2004.09.005

Nair, S. G., Golden, S. A., and Shaham, Y. (2008). Differential effects of the hypocretin 1 receptor antagonist SB 334867 on high-fat food self-administration and reinstatement of food seeking in rats. Br. J. Pharmacol. 154, 406-416. doi: 10.1038/bjp.2008.3

Nambu, T., Sakurai, T., Mizukami, K., Hosoya, Y., Yanagisawa, M., and Goto, K. (1999). Distribution of orexin neurons in the adult rat brain. Brain Res. 827, 243-260. doi: 10.1016/S0006-8993(99)01336-0

Peyron, C., Faraco, J., Rogers, W., Ripley, B., Overeem, S., Charnay, Y., et al. (2000). A mutation in a case of early onset narcolepsy and a generalized absence of hypocretin peptides in human narcoleptic brains. Nat. Med. 6, 991-997. doi: $10.1038 / 79690$

Peyron, C., Tighe, D. K., Van Den Pol, A. N., De Lecea, L., Heller, H. C., Sutcliffe, J. G., et al. (1998). Neurons containing hypocretin (orexin) project to multiple neuronal systems. J. Neurosci. 18, 9996-10015.

Piccoli, L., Micioni Di Bonaventura, M. V., Cifani, C., Costantini, V. J., Massagrande, M., Montanari, D., et al. (2012). Role of orexin-1 receptor mechanisms on compulsive food consumption in a model of binge eating in female rats. Neuropsychopharmacology 37, 1999-2011. doi: 10.1038/ npp. 2012.48

Putula, J., Turunen, P. M., Jäntti, M. H., Ekholm, M. E., and Kukkonen, J. P. (2011). Agonist ligand discrimination by the two orexin receptors depends on the expression system. Neurosci. Lett. 494, 57-60. doi: 10.1016/j.neulet.2011. 02.055

Sakurai, T., Amemiya, A., Ishii, M., Matsuzaki, I., Chemelli, R. M., Tanaka, H., et al. (1998). Orexins and orexin receptors: a family of hypothalamic neuropeptides and $\mathrm{G}$ protein-coupled receptors that regulate feeding behavior. Cell 92 , 573-585. doi: 10.1016/S0092-8674(00)80949-6

Selbach, O., Bohla, C., Barbara, A., Doreulee, N., Eriksson, K. S., Sergeeva, O. A., et al. (2010). Orexins/hypocretins control bistability of hippocampal long-term synaptic plasticity through co-activation of multiple kinases. Acta Physiol. (Oxf.) 198, 277-285. doi: 10.1111/j.1748-1716.2009.02021.x

Smart, D., Jerman, J. C., Brough, S. J., Rushton, S. L., Murdock, P. R., Jewitt, F., et al. (1999). Characterization of recombinant human orexin receptor pharmacology in a Chinese hamster ovary cell-line using FLIPR. Br. J. Pharmacol. 128, 1-3. doi: $10.1038 /$ sj.bjp. 0702780

Soffin, E. M., Gill, C. H., Brough, S. J., Jerman, J. C., and Davies, C. H. (2004). Pharmacological characterisation of the orexin receptor subtype mediating postsynaptic excitation in the rat dorsal raphe nucleus. Neuropharmacology 46, 1168-1176. doi: 10.1016/j.neuropharm.2004.02.014

Soya, S., Shoji, H., Hasegawa, E., Hondo, M., Miyakawa, T., Yanagisawa, M., et al. (2013). Orexin receptor- 1 in the locus coeruleus plays an important role in cue-dependent fear memory consolidation. J. Neurosci. 33, 14549-14557. doi: 10.1523/JNEUROSCI.1130-13.2013

Steiner, M. A., Lecourt, H., and Jenck, F. (2012). The brain orexin system and almorexant in fear-conditioned startle reactions in the rat. Psychopharmacology (Berl.) 223, 465-475. doi: 10.1007/s00213-012-2736-7

Thannickal, T. C., Moore, R. Y., Nienhuis, R., Ramanathan, L., Gulyani, S., Aldrich, M., et al. (2000). Reduced number of hypocretin neurons in human narcolepsy. Neuron 27, 469-474. doi: 10.1016/S0896-6273(00)00058-1

Trivedi, P., Yu, H., Macneil, D. J., Van Der Ploeg, L. H., and Guan, X. M. (1998). Distribution of orexin receptor mRNA in the rat brain. FEBS Lett. 438, 71-75. doi: 10.1016/S0014-5793(98)01266-6

Tsujino, N., and Sakurai, T. (2009). Orexin/hypocretin: a neuropeptide at the interface of sleep, energy homeostasis, and reward system. Pharmacol. Rev. 61, 162-176. doi: 10.1124/pr.109.001321

Tsunematsu, T., Kilduff, T. S., Boyden, E. S., Takahashi, S., Tominaga, M., and Yamanaka, A. (2011). Acute optogenetic silencing of orexin/hypocretin neurons induces slow-wave sleep in mice. J. Neurosci. 31, 10529-10539. doi: 10.1523/JNEUROSCI.0784-11.2011

Uramura, K., Funahashi, H., Muroya, S., Shioda, S., Takigawa, M., and Yada, T. (2001). Orexin-a activates phospholipase C- and protein kinase C-mediated $\mathrm{Ca} 2+$ signaling in dopamine neurons of the ventral tegmental area. Neuroreport 12, 1885-1889. doi: 10.1097/00001756-200107030-00024

Uslaner, J. M., Tye, S. J., Eddins, D. M., Wang, X., Fox, S. V., Savitz, A. T., et al. (2013). Orexin receptor antagonists differ from standard sleep drugs by promoting sleep at doses that do not disrupt cognition. Sci. Transl. Med. 5, 179 ral44. doi: 10.1126/scitranslmed.3005213

Valentino, R. J., and Van Bockstaele, E. (2008). Convergent regulation of locus coeruleus activity as an adaptive response to stress. Eur. J. Pharmacol. 583, 194-203. doi: 10.1016/j.ejphar.2007.11.062

Valko, P. O., Gavrilov, Y. V., Yamamoto, M., Reddy, H., Haybaeck, J., Mignot, E., et al. (2013). Increase of histaminergic tuberomammillary neurons in narcolepsy. Ann. Neurol. doi: 10.1002/ana.24019. [Epub ahead of print].

Van Den Pol, A. N. (1999). Hypothalamic hypocretin (orexin): robust innervation of the spinal cord. J. Neurosci. 19, 3171-3182.

Van Den Pol, A. N., Gao, X. B., Obrietan, K., Kilduff, T. S., and Belousov, A. B. (1998). Presynaptic and postsynaptic actions and modulation of neuroendocrine neurons by a new hypothalamic peptide, hypocretin/orexin. J. Neurosci. 18, 7962-7971.

Vincent, S. R., Satoh, K., Armstrong, D. M., and Fibiger, H. C. (1983). NADPHDiaphorase: A selective histochemical marker for the cholinergic neurons of the pontine reticular formation. Neurosci. Lett. 43, 31-36. doi: 10.1016/03043940(83)90124-6

Willie, J. T., Chemelli, R. M., Sinton, C. M., Tokita, S., Williams, S. C., Kisanuki, Y. Y., et al. (2003). Distinct narcolepsy syndromes in orexin receptor-2 and orexin null mice. molecular genetic dissection of non-REM and REM sleep regulatory processes. Neuron 38, 715-730. doi: 10.1016/S0896-6273(03) 00330-1

Winrow, C. J., and Renger, J. J. (2013). Discovery and development of orexin receptor antagonists as therapeutics for insomnia. Br. J. Pharmacol. doi: 10.1111/bph. 12261. [Epub ahead of print].

Winskey-Sommerer, R., Yamanaka, A., Diano, S., Borok, E., Roberts, A. J., Sakurai, T., et al. (2004). Interaction between corticotropin-releasing factor system and hypocretins (Orexins): a novel circuit mediating stress response. J. Neurosci. 24, 11439-11448. doi: 10.1523/JNEUROSCI.3459-04.2004

Wu, M., Zaborszky, L., Hajszan, T., Van Den Pol, A. N., and Alreja, M. (2004). Hypocretin/orexin innervation and excitation of identified septohippocampal cholinergic neurons. J. Neurosci. 24, 3527-3536. doi: 10.1523/JNEUROSCI.5364-03.2004

Wu, M., Zhang, Z., Leranth, C., Xu, C., Van Den Pol, A. N., and Alreja, M. (2002) Hypocretin increases impulse flow in the septohippocampal GABAergic pathway: implications for arousal via a mechanism of hippocampal disinhibition. J. Neurosci. 22, 7754-7765.

Xi, M., Morales, F. R., and Chase, M. H. (2001). Effects on sleep and wakefulness of the injection of hypocretin-1 (orexin-A) into the laterodorsal tegmental nucleus of the cat. Brain Res. 901, 259-264. doi: 10.1016/S0006-8993(01) 02317-4

Xu, R., Wang, Q., Yan, M., Hernandez, M., Gong, C., Boon, W. C., et al. (2002). Orexin-A augments voltage-gated Ca2+ currents and synergistically increases growth hormone $(\mathrm{GH})$ secretion with $\mathrm{GH}$-releasing hormone in 
primary cultured ovine somatotropes. Endocrinology 143, 4609-4619. doi: 10.1210/en.2002-220506

Yamanaka, A., Tabuchi, S., Tsunematsu, T., Fukazawa, Y., and Tominaga, M. (2010). Orexin directly excites orexin neurons through orexin 2 receptor. J. Neurosci. 30, 12642-12652. doi: 10.1523/JNEUROSCI.2120-10.2010

Yang, B., and Ferguson, A. V. (2002). Orexin-A depolarizes dissociated rat area postrema neurons through activation of a nonselective cationic conductance. J. Neurosci. 22, 6303-6308.

Yang, B., and Ferguson, A. V. (2003). Orexin-A depolarizes nucleus tractus solitarius neurons through effects on nonselective cationic and $\mathrm{K}+$ conductances. J. Neurophysiol. 89, 2167-2175. doi: 10.1152/jn.01088.2002

Conflict of Interest Statement: The authors declare that the research was conducted in the absence of any commercial or financial relationships that could be construed as a potential conflict of interest.
Received: 31 October 2013; accepted: 29 November 2013; published online: 20 December 2013.

Citation: Kohlmeier KA, Tyler CJ, Kalogiannis M, Ishibashi M, Kristensen MP, Gumenchuk I, Chemelli RM, Kisanuki YY, Yanagisawa M and Leonard CS (2013) Differential actions of orexin receptors in brainstem cholinergic and monoaminergic neurons revealed by receptor knockouts: implications for orexinergic signaling in arousal and narcolepsy. Front. Neurosci. 7:246. doi: 10.3389/fnins.2013.00246

This article was submitted to Neuropharmacology, a section of the journal Frontiers in Neuroscience.

Copyright (C) 2013 Kohlmeier, Tyler, Kalogiannis, Ishibashi, Kristensen, Gumenchuk, Chemelli, Kisanuki, Yanagisawa and Leonard. This is an open-access article distributed under the terms of the Creative Commons Attribution License (CC BY). The use, distribution or reproduction in other forums is permitted, provided the original author(s) or licensor are credited and that the original publication in this journal is cited, in accordance with accepted academic practice. No use, distribution or reproduction is permitted which does not comply with these terms. 